\title{
Public support for R\&D, knowledge sourcing and firm innovation: Examining a mediated model with evidence from the manufacturing industries
}

\begin{abstract}
The aim of this study is to examine how firms realize the benefits associated with public support for R\&D programs. To do so, this research examines whether a public intervention through R\&D subsidies leads companies to enhance their knowledge sourcing activities. Then, the study assesses whether the policy-induced effect on the firms' knowledge sourcing also has a positive impact on their innovative performance. Using panel data for Spanish manufacturing companies for the period 1998-2005, the findings provide evidence indicating that public R\&D subsides enhance the firms' R\&D effort and levels of openness adopted in their innovations. In addition, the results show that, by inducing these changes, public intervention affects firm innovation, as measured by patent application and new product introduction counts. The implications of these results for the literature on technology-policy evaluation and innovation management are discussed.
\end{abstract}




\section{Introduction}

Innovation is a challenging process. It requires that firms build problem-solving capabilities through which solutions to valuable innovation problems can be generated. As documented by prior studies on innovation management, knowledge sourcing has a potentially important role in allowing firms to acquire and develop needed problem-solving capabilities (Katila and Ahuja, 2002; Laursen and Salter, 2006; Rosenkopf and Nerkar, 2001). However, the formation of these capabilities may be affected by the presence of market and system failures (Falk, 2007; Gelabert et al., 2009). On the one hand, market failures arise because innovation is fundamentally a process of knowledge production that suffers from imperfect appropriability (Arrow, 1962). The fact that firms cannot entirely appropriate the returns generated by their innovations lead them to underinvest in $R \& D$ activities. On the other hand, system failures emerge because the acquisition of external knowledge needed for firm innovation is fraught with complexities and contractual problems that may affect the scope of inter-organizational learning (Gök and Edler, 2012). Because internal and external R\&D provide a basis for sustaining knowledge sourcing, imperfect appropriability and the costs of external knowledge acquisition may impair firm innovation in substantial ways. Innovation policy is then justified as an instrument that allows policy makers to mitigate the negative impact of market and system failures on firms' knowledge-sourcing behavior.

Considering the presence of market and system failures, the contribution of R\&D subsidies has been evaluated according to presence of additionality effects. The positive impact of R\&D subsidies in terms of additional firms' R\&D expenditures are viewed as a form of input additionality, while the positive effects in terms of further innovation outcomes are considered as a manifestation of output additionality (David et al., 2000; Klette et al., 2000; Mairesse and Mohnen, 2010). Recent studies have started to evaluate the presence of behavioral changes in supported firms induced by R\&D assistance programs, or what is called behavioral additionality (Knockaert et al., 2014; Wanzenböck et al., 2013).

Despite the progress provided by prior studies, the evaluation of innovation policy 
still offers a partial view of the total impact of R\&D policy on firm innovation. On the one hand, input and behavioral additionality conceptualizations focus the attention on the assessment of intermediate effects, such as the creation of technological knowledge or the development of supported firms' learning capabilities. Nonetheless, less attention is placed on examining how these effects shape the innovative performances of assisted firms. In some cases, it is assumed that the effects of input or behavioral additionality will be eventually translated into increased innovation outcomes (Falk, 2007). On the other hand, evaluation of output additionality disregards the process that links public support for R\&D and firm innovation. The characterization of this process is important for distinguishing the effects genuinely attributable to public intervention from those caused by other factors that also drive firm innovation.

In this study, we assess the impact of public intervention via R\&D subsidies on firm innovation. Apart from the evaluation of the direct impact associated with public intervention, we also consider a more subtle indirect effect, which runs through policy-induced changes in the knowledge sourcing activities of supported companies. Specifically, our focus is on assessing whether government support for $R \& D$ improves the innovation outcome of companies by enhancing their knowledge sourcing activities, defined here by the $R \& D$ effort of firms and levels of openness in their innovations. Using panel data for Spanish manufacturing companies during the period 1998-2005, the study confirms the presence of intermediate effects like the enhancement of firms' knowledge sourcing activities that are attributable to National R\&D subsidy programs. Most importantly, the study reports evidence to indicate that some of these intermediate effects also contribute to increasing the patent activity of firms and their capacity to make new product introductions. For instance, the results show that policy-induced increments in firms' R\&D effort and propensity to use technology and labor markets also translate into increases in their patent applications. Likewise, reported findings show that R\&D subsidies positively affect the number of firms' new product introductions exclusively by increasing their R\&D effort and propensity to form 
technology cooperation.

Our research contributes to the literature on technology-policy evaluation in the following ways. First, in assessing the innovation consequences attributable to input and behavioral additionality, it provides an integrative and more comprehensive perspective to evaluate the effects derived from public support for R\&D. Some recent studies have begun to assess the indirect impact of technology policy on firm innovation (Czarnitzki and Licht, 2006; Hussinger, 2008; Kang and Park, 2012; Lee and Wong, 2009). Our study advances these contributions by assessing how policy-induced changes on both internal and external knowledge sourcing activities affect different indicators of innovation outcomes (i.e., patent and new product introduction counts). In addition, our study is among the first in assessing the indirect effects of public intervention on firm innovation that run not only through $R \& D$ collaboration deals, but also through other external knowledge sourcing activities, such as technology markets and labor markets. On the other hand, compared to prior studies, our evaluation assesses the innovation consequences of indirect effects by using panel data methods and instrumental variable techniques. In doing so, the study is better able to account for the presence of widely recognized sources of unobservable heterogeneity, which may cause biases in the estimation of the impact of public support for R\&D on firm innovation.

\section{Conceptual background}

\subsection{Direct effect of public R\&D funding on firms' innovative performance}

Part of the literature on innovation-policy evaluation is focused on assessing the direct effect of public support for R\&D on a firm's innovation output, or what is defined as output additionality. Roper et al. (2004) and Hewitt-Dundas and Roper (2010) identify a range of mechanisms that link public support for R\&D and firms' innovative performance. These authors indicate that government R\&D programs help supported firms build stocks of knowledge for their innovation, increase their abilities to conduct future research projects, form innovative capabilities and develop their human resources. Without identifying which of the aforementioned mechanisms prevail in explaining the relationship between public 
support for R\&D and firms' innovation, an important stream of works provide evidence showing the existence of output additionality. Klette et al. (2000) review a set of microeconometric studies to assess the impact of alternative policy intervention schemes. The results show a range of effects, including enhanced patenting capabilities, increased sales, and employment growth, all of which indicate the existence of output additionality.

More recent evaluation studies confirm the presence of output additionality relating to direct and indirect R\&D policy schemes, namely R\&D subsidies and tax credit incentives, respectively. As regards marketable outputs, Hujer and Radić (2005) examine the impact of R\&D subsidies in the case of Germany, finding evidence of additionality as measured by the firms' propensity to make new product/service introductions. In terms of indirect schemes, Cappelen et al. (2012) confirm that R\&D tax-credits raise the propensity of firms to patent and launch new products in the case of Norway. As regards commercial outputs, HewittDundas and Roper (2010) find that public support for Ireland and Northern Ireland increases firms' sales relating to upgraded as well as new product introductions. For the case of indirect mechanisms of public assistance, Bérubé and Mohnen (2009) show that highly supported firms in Canada, those receiving grants and R\&D tax-incentives, have a high propensity to introduce new products and be more successful in their commercialization than their non-supported counterparts that receive only R\&D tax-incentives.

Despite the relevance of previous findings, technology policy assessment in output additionality conceives firm innovation as a black-box process, in which the focus is on determining the link between public intervention and firm innovation, and not on identifying the channels through which supported firms translate the benefits of public assistance into innovation outcomes.

\subsection{The intermediate effects of public R\&D funding}

Instead of assessing the effect of public intervention on firms' innovation outcomes, other approaches focus the attention on the determination of intermediate effects, such as growth of privately funded R\&D expenditures, creation of technological knowledge, or 
development of supported firms' learning capabilities. Input additionality and behavioral additionality are two approaches being developed for the assessment of these intermediate effects. Based on the reasoning of market failure, input additionality establishes that a public intervention is effective when it causes supported firms to invest at least one additional monetary unit for every monetary unit granted by public assistant programs. Examination of the input additionality literature provides ample evidence indicating the presence of crowd-in effects, according to which public assistant boosts private R\&D expenditures (Almus and Czarnitzki, 2003; Czarnitzki and Lopes-Bento, 2012; Duguet, 2004; Gelabert et al., 2009; González et al., 2005).

Recent studies have started to use a complementary perspective to evaluate the influence of public intervention on the innovation process itself. Based on the logic of system failure, the attention is on the presence of behavioral additionality, as firstly defined by Buisseret el al. (1995), or behavioral changes in supported firms induced by public assistance. This perspective emerges as a response to the extended recognition among scholars and policy makers that public intervention not only provides financial resources, but also produces learning effects that can influence the way firms organize their innovation activities. For instance, Georghiou et al. (2004) acknowledge that public intervention generates behavioral additionality when instruments of innovation policy interact with the strategies and capabilities of supported firms. From this interaction, firms can learn from knowledge spillovers and from the exposures to the strategies, routines, and capabilities of those organizations involved in public funded projects.

In terms of identifying intermediate effects caused by input and behavioral additionality, knowledge acquisition is recognized as one important dimension of the innovation process that can be affected by public intervention (Falk, 2007; Georghiou et al., 2004; Kang and Park, 2012). Prior research has proposed several conceptualizations to assess the impact of technology policy on the knowledge-acquisition behavior of firms. Among the most commonly used, we find the notions of scale additionalityand scope 
additionality. Public intervention produces scale additionality if supported firms enlarge the scale of their knowledge-acquisition activities, and scope additionality, if supported firms increase the coverage of these activities to a broader range of technological fields (Falk, 2007; Georghiou et al., 2004; Wanzenböck et al., 2013). Recent studies have also started to evaluate the impact of technology policy in terms of changes in the way supported firms acquire knowledge from external sources (Afcha, 2011; Busom and Fernández-Ribas, 2008; Mohnen and Hoareau, 2003). In this case, the notion of collaboration additionality is adopted to describe the impact of public intervention on the strategies implemented by companies when they source problem-solving capabilities from collaboration agreements (Roper and Hewitt-Dundas, 2012).

Policy evaluation on intermediate effects is useful to identify important changes in the knowledge-sourcing behavior of supported companies. However, the evaluation of technology policy based on intermediate effects is limited. In the case of input additionality, the evaluation is mostly based on the acquisition of technological knowledge and not on the part of the innovation process in which supported firms transform that knowledge into innovation outcomes. The evaluation based on behavioral additionality recognizes a broad range of effects, but less attention is still paid to the examination of the link between behavioral changes and firm innovation. These conceptualizations implicitly assume that changes in inputs and behaviors are for the better, and consequently, they should translate into innovation outcomes with potential commercial value (Falk, 2007). Nonetheless, these approaches disregard the description of the channels by which their involved intermediate effects enhance innovation outcomes.

\subsection{Knowledge sourcing as an intervening mechanism linking public support for R\&D and firm innovation}

Given the findings reported by prior studies on technology-policy evaluation, in this research our aim is to examine whether there is an indirect effect of a public intervention on the innovation outcomes of supported companies, running through changes in their knowledge sourcing behavior. Hence, our focus is on determining if knowledge sourcing 
activities are mediating mechanisms in the relationship between public support for R\&D and firm innovation. To examine whether knowledge sourcing channels a public intervention impact into firm innovation, the attention is on analyzing the innovation consequences caused by induced changes in the R\&D adoption behavior of supported firms. In this study, we characterize the knowledge sourcing of a firm by (i) the R\&D effort it chooses, and (ii) the degree of openness it adopts for its innovation activities.

Our focus on these forms of knowledge sourcing is justified by the following reasons. On the one hand, a firm's investment in intramural R\&D comprises a prominent mechanism for achieving knowledge intended to solve underlying problems emerging during the innovation process (Helfat, 1994; Nerkar, 2003). These investments uncover the effort made by a firm in searching and implementing solutions to improve the performance of a technology and/or a product design (Pisano, 2000). On the other hand, firms may acquire essential knowledge for their innovations from external sources. Because of recent trends in technology evolution, firms' innovations requires the use and integration of several knowledge bases, some of which are embedded in their environment (Lakhani et al., 2013). As a result, intramural $R \& D$ is no longer enough to achieve a leading-edge in innovation (Cassiman and Veugelers, 2006). To handle this issue, many firms can develop technology and product development models that foster the use of external knowledge sources (Chesbrough, 2006; Laursen and Salter, 2006; Powell et al., 1996). The formation of alliances along with the use of market-based arrangements are two established mechanisms that assist firms in obtaining required problem-solving capabilities from external sources (Grant and Baden-Fuller, 2004; West and Bogers, 2014).

Here, it is anticipated that policy-induced effects on previously described knowledge sourcing dimensions increase firm innovation given the largely recognized role of these dimensions in facilitating the development of the problem-solving capabilities a firm requires for the generation of new technologies and/or product designs (Cassiman and Veugelers, 2006; Katila and Ahuja, 2002; Laursen and Salter, 2006). Next section discusses the potential 
effects of public intervention on the knowledge sourcing of firms. Then, the involved innovative effects are considered.

\subsubsection{Public intervention effects running through the firm's R\&D effort}

In line with the findings reported by prior studies on technology-policy evaluation, our aim is to verify the premise that firms receiving R\&D public funding will increase knowledge sourcing occurring in their intramural R\&D activities. Two mechanisms can be used for explaining this policy-induced effect. First, when firms engage in publicly funded projects, they gain experience in executing, organizing and managing the involved R\&D activities. In line with the suggestion of Roper et al. (2004), this experience helps supported companies develop R\&D management capabilities, hence favoring the future undertaking of privately funded R\&D activities. This fact holds true because the formation of R\&D management capabilities produces productivity gains that reduce the costs a firm faces in the organization of subsequent R\&D activities. For instance, firms building these capabilities can determine more easily the target of future R\&D projects and evaluate their potential value than those lacking such capabilities (Clarysse et al., 2009). Second, from the execution of publicly funded projects, supported firms can generate technological opportunities that lead to new R\&D projects. This comes about because publicly funded R\&D provide outputs, such as new knowledge and problem-solving capabilities that supported firms might use to develop their on-going projects and/or begin new ventures. For instance, involvement in $R \& D$ grant programs might enable supported firms to identify relevant innovation problems or discover solutions to some others, opening in this way new avenues for the development of alternative R\&D projects. This fact is consistent with the idea of Lee (2011) that publicly funded R\&D projects generate knowledge spillovers that may enhance the technological performance of the supported companies' R\&D activities.

If engagements in public R\&D granted programs lead firms to increase its R\&D effort, then an interesting policy issue is to examine whether the induced increments in intramural $R \& D$ translate to a superior innovative performance. Since firm innovation is a relevant target 
of many public R\&D funding programs, it is important to determine if the intermediate effects associated with public intervention finally brings superior innovation outcomes. In line with studies on technology and innovation (Katila and Chen, 2008; Pisano, 2000; Rosenkopf and Nerkar, 2001), we expect that policy-induced efforts in sourcing knowledge from intramural R\&D generate new knowledge that expands the technological space in which firms may find solutions for their technology and product development process. In doing so, we further anticipate that new possibilities of knowledge association will materialize, thus favoring increases in supported firms' innovation capabilities.

Prior suggestions indicate that R\&D subsidy programs may affect firm innovation indirectly by increasing knowledge sourcing occurring via intramural R\&D. Despite its policy implications, few studies have assessed this indirect effect. Notable exceptions are found in the following three studies. First, Czarnitzki and Licht (2006) show that participations in public R\&D grant programs in the case of West and East Germany is associated with increments in the R\&D effort of supported companies. Moreover, their study reveals that R\&D expenditures stimulated by public funding further increase the supported firms' patent application propensity. Second, Hussinger (2008) reports evidence for a sample of German manufacturing companies that policy-induced R\&D contributes to enhanced new product sales. Third, for a sample of a biotechnology companies in South Korea, Kang and Park (2012) find evidence to indicate that governmental support through funding R\&D projects indirectly affects firms' innovation by boosting internal R\&D activities. All these findings reject the premise that R\&D subsidies lead companies to spend inefficiently, for example, by increasing the wages of R\&D personnel without an involved productivity gain. They also discard the presence of reallocation effects in which supported firms adjust their R\&D portfolio toward technologies that make them less productive in producing innovations.

\subsubsection{Public intervention effects running through the openness in firm innovation}

Here, it is also suggested that participation in public R\&D grant programs can encourage supported companies to obtain knowledge from external sources. As in the case 
of intramural R\&D, the presence of experience effects and technological opportunities provoked by public R\&D grant programs are used for explaining why supported firms may acquire knowledge from external sources. First, earlier research on technology policy indicates that, apart from the gained experience in managing the involved R\&D activities, the undertaking of publicly R\&D projects also leads supported companies to build stocks of knowledge (Lee, 2011; Roper et al., 2004). An important implication of this is that the formation of these stocks also makes supported firms more able to identify, assimilate and apply external knowledge that is associated with the technological fields comprising such stocks. This idea is coherent with the conceptualization of absorptive capacity, according to which the degree of external knowledge utilization is a function of the level of related prior knowledge a firm accumulates (Cohen and Levinthal, 1990). Preceding arguments suggest that the openness adopted by a supported firm to source knowledge is created as a byproduct of its involvement in publicly funded R\&D projects. For instance, if a company receives public funding to develop a R\&D project related to the technology " $\mathrm{X}$ ", our suggestion indicates that this firm will be better ready to identify the importance of external knowledge associated with " $X$ ". Because of the formation of absorptive capacity in " $X$ ", it is anticipated that public intervention would enable this firm to obtain and apply external knowledge connected to " $X$ " in its own innovations. While the absorptive capacity resulting from the execution of publicly funded projects reduces the costs of acquiring external knowledge, it is expected that supported firms are more willing to form alliances and/or to use market-based contracts to source external knowledge for its innovations.

Second, the exploitation of part of the technological opportunities created by the execution of publicly R\&D projects may require that supported companies acquire complementary problem-solving capabilities from external sources (Lee and Wong, 2009). For instance, solutions generated from the execution of public R\&D projects can be subsequently developed by supported companies using resources and complementary knowledge obtained from other agents, such as universities, research centers and other 
companies. Similarly, identified innovation problems in publicly funded projects might require the access to technological solutions coming from other organizations, which would lead supported companies to form links like R\&D alliances and market-based agreements to obtain such solutions. This position is coherent with the premise that being recipient firm of public R\&D support and thus performing public R\&D projects may generate new technological necessities that may lead not only to intensify knowledge sourcing occurring via intramural $R \& D$, but also to open the knowledge sourcing activities of supported companies.

While the execution of publicly R\&D projects may lead supported firms to source external knowledge, an important policy issue is to determine whether this policy-induced effect also involves a superior innovative performance for the supported companies. The examination of this issue is relevant to assess adequately the scope of public programs in promoting R\&D activities. Here, our suggestion is that programs encouraging firms to source external knowledge should bring subsequent positive innovative performance effects. The main reason that sustains this claim is that the use of external knowledge facilitates the emergence of new possibilities for knowledge recombination (Fleming and Sorenson, 2001; Rosenkopf and Nerkar, 2001). As widely recognized by studies on technology and innovation, R\&D collaborations and knowledge-acquisitions in technology markets are prominent mechanisms to acquire new knowledge (Almeida et al., 2003; Grant and Baden-Fuller, 2004; Mowery et al., 1996; Powell et al., 1996). For instance, the use of alliances and market-based deals provides firms with mechanisms that enable knowledge transfer and the internalization of technological opportunities existing in their environments (Gomes-Casseres et al., 2006). Thus, these arrangements help firms channel external knowledge into the site where their problem-solving capabilities are placed. In doing so, firms can extend the technological space from which new knowledge combinations might arise for the solution of relevant innovation problems (Katila and Chen, 2008). With an extended technological space, innovation is more likely to occur because firms face more possibilities to recombine 
existing knowledge and solutions, or reconfigure the ways knowledge elements are linked (Phelps, 2010). An implication of these ideas is that induced-policy changes toward the use of external knowledge sources strategies might increase the innovative performance of supported companies. As a result, the evaluation of programs based on the grant of R\&D funding should consider the indirect effect on firm innovation running through an induced willingness of supported companies to source external knowledge.

Despite being relevant for a suitable evaluation of an innovation policy, very few studies have assessed the presence of this indirect effect. Notable exceptions are found in the case of Lee and Wong (2009) and Kang and Park (2012). In the first case, the study uses mediation analysis to assess the indirect effect of public intervention on supported firms' product and process innovations, transmitted through the formation of R\&D collaborations. For a sample of manufacturing small-medium size enterprises (SME) for Singapore, the authors report evidence indicating that supported companies have a strong propensity to form R\&D collaboration deals, and in doing so, public intervention favors product and process innovation for these companies. In the second case, the study documents the existence of indirect effects, according to which government support for R\&D impacts firms' patenting propensity by allowing firms' participation in domestic and downstream alliances. Taken together, these results indicate that a proper evaluation of the impact of public R\&D grant should consider potential consequences of public intervention in changing not only the R\&D effort of supported firms, but also their external knowledge sourcing behavior. In this way, technology-policy evaluation could capture a broader range of the effects that are relevant for enhancing the innovation prospects of recipient companies.

In order to summarize prior ideas, Figure 1 presents the mediated model that describes the potential role of knowledge sourcing in linking public support from R\&D and firms' innovative performance. Next sections will explain in more details the data and methods implemented in the study to assess the direct and indirect effects of public R\&D grants depicted by Figure 1. 
[Insert Fig. 1 here]

\section{Empirical analysis}

\subsection{Data}

The analysis in this study makes use of data coming from the Survey of Business Strategy (ESEE, its Spanish acronym). The ESEE is a firm-year level panel conducted by the Fundación Empresa Pública, in collaboration with the Spanish Ministry of Industry. Starting in 1990 , the survey gathers detailed information on several dimensions of firms' business strategies and includes an average sample of 1,800 manufacturing companies. The ESEE is an unbalanced panel because some companies stopped providing information for reasons such as mergers, shutdown or liquidation. To preserve representativeness, new companies are included in the survey each year. The ESEE provides information on firms operating in all Spanish manufacturing industries, classified according to the two digit-level NACE industry classification (Statistical classification of economic activities in the European Community). The survey is exhaustive for firms with more than 200 employees. For firms having between 10 and 200 employees, a stratified random sample is collected by industry and firm size intervals.

As relevant information about the use of knowledge-sourcing strategies (e.g., R\&D alliances, technology in-licensing or R\&D outsourcing) was incorporated into the survey in 1998, we built a longitudinal sample for the period 1998-2005. Some of the methods used in the study require no gaps in the within-firm time series ${ }^{1}$. With this requirement, our sample comprises observations (firms) with at least two consecutive values for all the variables under consideration. After taking away observations with missing values, the sample includes 1,567 firms and 10,118 firm-year observations. In our sample, $11.93 \%$ of the companies received public funds from the Spanish government at least once during the period 1998-2005.

Table 1 shows the breakdown of the sample by industry type, support status and firm

\footnotetext{
${ }^{1}$ In particular, these requirements are imposed on the estimation of the model used here to explain the firms' innovative performance.
} 
size. Industries were classified as low- or high-tech intensive, according to OECD taxonomy (2005). Table 1 reveals that the probability of being a supported company is larger for hightech industries. During the period under consideration, we can observe that high-tech industries concentrate larger shares of small-to-medium size firms (200 or fewer employees), while the distribution between small and large companies is more balanced in low-tech industries.

\section{[Insert Table 1 here]}

Our sample covers a period in which the Spanish innovation system had a poor performance, as suggested by some of the indicators traditionally used to monitor developments in science and technology (COTEC, 2007). For instance, for the period 19982005 , total Spanish expenditure on R\&D with respect to gross domestic product (GDP) was half the European Union average (Vega-Jurado et al., 2009). Additionally, data from the Community Innovation Survey reveal that the rate of technological cooperation in Spain, particularly between firms and public institutions such as universities and research centers is below the European Union average (Busom and Fernández-Ribas, 2008). On the other hand, the Spanish innovation system for the period $1998-2005$ is characterized by the dominant role of the public sector in the composition of the national expenditures in R\&D. For instance, in 2003 total public expenditures in R\&D were $40.1 \%$ in Spain, while this proportion reached $34.7 \%$ in the entire European Union (Segarra-Blasco and Arauzo-Carod, 2008). The contribution of Spanish business sectors to national expenditures in R\&D was one of the lowest among the OECD countries over the 1998-2005 period (COTEC, 2007). Given the information gathered by the ESSE on direct mechanisms of public intervention, the study is in a good position to assess potential effects of Spanish R\&D subsidy programs on inducing changes in the innovative behavior of the surveyed companies.

\subsection{R\&D support for firms in Spain}

In this research, the attention is placed on support provided by the Spanish government via R\&D subsidies. Unfortunately, the ESEE does not provide disaggregated 
information to identify specific national programs from which firms can obtain R\&D subsidies. As in the case of other studies on technology-policy evaluation (Busom and Fernández-Ribas, 2008; Czarnitzki and Licht, 2006; Gelabert et al., 2009; Hussinger, 2008), the analysis here is done at an aggregate level by assessing the "average" impact of public intervention related to $R \& D$ subsidies on firm innovation for the period under question. In particular, the study focuses on R\&D subsidies coming mainly from sources like the National Plan for Scientific Research and Technological Development (National R\&D Plan). This plan has been the most important policy instrument used in Spain for articulating policy actions intended to improve the technological performance of the country's innovation system since 1998 (Busom and Fernández-Ribas, 2008). Thenceforth, the National R\&D plan has pursued several objectives, among which we can highlight the increase of business R\&D expenditures and the number of researchers hired by companies, the promotion of programs for the use of new technologies, and the raise of firms' participation in cooperative research projects, particularly between companies and public institutions, such as universities and research centers. The Center for the Development of Industrial Technology (CDTI) has been the public entity responsible for channeling the funding included in the National R\&D Plan (Ballesteros and Rico, 2001). All these programs include mechanisms that range from R\&D subsidies, soft credits, to equity co-investment projects. However, given data limitations, here the focus is on programs based on R\&D subsidies.

The process of public funding allocation through the CDTI is as follows. A public call is announced and firms decide whether to apply. After evaluating the applications, a group of proposals is selected for being granted. In a study of the evaluation process followed by the CDTI, Huergo and Trenado (2010) define the general criteria considered by the agency to grant R\&D support. The following items are considered in the assessment process: (i) scientific-technical quality of the proposals, (ii) degree of innovation of the projects, (iii) technical and financial capabilities of the applicant firms to undertake the projects, iv) firms' abilities to exploit potential outcomes of the projects, $(v)$ potential market value of the 
outcomes derived by the projects, and (vi) fulfillment of encouraging effect. These authors also uncover the drivers explaining the likelihood of applicant firms to receive support. In their study, it is indicated that the degree of R\&D intensity associated with the project, the existence of firms' technical capability for the development of the project, and the export possibilities involved by the project are the most important factors shaping the grant decision of the agency (Huergo and Trenado, 2010).

\subsection{Variables}

\subsubsection{Dependent variables}

Innovative performance: We measured this multidimensional construct by using two alternative indicators: patent application counts and new product introduction counts. With these variables, our objective is to characterize two dimensions of the innovation process that are of central importance in the impact evaluation of R\&D subsidies: (i) the firm's inventiveness and (ii) the firm's new product development capabilities (Clarysse et al., 2009; Czarnitzki et al., 2007; Falk, 2007). On the one hand, prior studies of innovation and technology often conceive patents as the output from a knowledge-production function, which describes how firms build new knowledge from R\&D activities (Ahuja, 2000; Cincera, 1997; Hausman et al., 1984; Nerkar, 2003; Rothaermel and Alexandre, 2009). On the other hand, prior studies of organizational learning commonly view new product introductions as a measure indicating the firm's abilities to apply sourced knowledge in the generation of products with the capacity to fulfill emerging or existing customers' needs (Blundell et al., 1995; Nerkar and Roberts, 2004; Salomon and Shaver, 2005). In this regard, new product introductions are viewed as important elements of firm innovation capabilities (Katila and Ahuja, 2002).

However, we also acknowledge some limitations of these measures. Despite being an indicator of a firm's inventiveness, patents can be at the same time the outcome of other strategies, such as preventing possible hold-up problems in the market for technology or blocking a competitor's entry (Laursen and Salter, 2006). Furthermore, patent counts may underestimate a firm's innovation. This holds true because many innovations are only partly 
covered by patent protection, or not covered at all (Griliches, 1991; Klevorick et al., 1995; Sidhu et al., 2007). On the other hand, although new product introductions reflect a firm's innovativeness, it does not necessarily quantify the extent to which such introductions generate commercial value. For instance, companies may fail in maximizing the fit with their customers' needs while developing new products (Schilling and Hill, 1998). In this case, new product introductions will not be translated into increased sales and the firm's growth (Schilling, 2012). Despite this limitation, some studies also suggest that new product introductions positively correlate with sales growth and market value (Banbury and Mitchell, 1995; Katila and Ahuja, 2002; Scherer, 1983). Given prior limitations, we recognize that our empirical design measures the potential effects of public intervention on firm innovation imperfectly.

\subsubsection{Mediator variables}

$R \& D$ effort: To characterize this dimension of the firm's knowledge-sourcing behavior, the indicator R\&D intensity, measured as firms' R\&D private expenditure divided by firms' total sales, was built. Here, we assumed that, when a firm increases its R\&D effort, it also modifies important attributes of its knowledge sourcing behavior, such as the scale and/or scope of its R\&D projects. Thus, in the study of the effects derived from R\&D subsidies, we think this variable enables examination of whether public intervention modifies the knowledge sourcing behavior of supported companies.

Openness in innovation. We assumed that firms open their innovation activities by: (i) forming technology alliances (Grant and Baden-Fuller, 2004), (ii) acquiring knowledge in the markets for technology (Arora et al., 2004; Laursen et al., 2010), (iii) hiring qualified employees (Hess and Rothaermel, 2011), and (iv) using consultant expertise to obtain information about relevant technologies (Santamaria et al., 2010). The following dummies variables were considered to indicate the use of the previously described external knowledge sources activities. The first dummy takes the value of 1 when the firms stated that they formed R\&D alliances in the form of joint ventures or non-equity based agreements. The 
second dummy is equal to 1 when the firms acquired knowledge in the marketplace using licensing-in or R\&D outsourcing deals. The third dummy awards the value of 1 when the firms claimed they hired employees with experience in R\&D in other companies or from public institutions, such as universities or research centers. The last dummy is equal to 1 when the firms used consulting services to obtain information about valuable technologies.

\subsubsection{Independent variable}

Public funding for R\&D. our subsidy measure refers to the log of the total amount of public funding received annually by each firm from R\&D subsidy programs like the National R\&D Plan. Although the ESEE allows distinction among regional, national and other programs, our focus is on funding granted by the Spanish government. Several reasons justify this choice. First, subsidies granted by these programs constitute the main source of public funding in Spain (COTEC, 2007). Second, since sources of funding differ from one another in terms of technology policy objectives, eligibility and selection criteria, and amounts of funding, the use of an aggregate measure containing several program types may be problematic (Busom and Fernández-Ribas, 2008). For instance, aggregation would make it difficult to distinguish between the effects of public support on both innovative performance and knowledge-sourcing dimensions from those due to the specific characteristics of each program. Third, since a firm's openness to innovation is a requirement commonly imposed by European agencies to grant R\&D support, the inclusion of European funding as a part of the independent variable could create a problem of endogeneity that would affect the results of the evaluation policy in the study (Blanes and Busom, 2004).

\subsubsection{Control variables}

Firm-specific characteristics. First, we accounted for the firm's predisposition to explore new technologies because this aspect can determine the scope of its intramural R\&D activities as well as the breadth of its external knowledge-sourcing strategies. Moreover, companies that are more exploratory are also well positioned to make innovations. Exploration was measured by the variable, technological assessment, which is a dummy variable that takes the value of 1 when firms asserted that they evaluated alternative 
technologies or perspectives of technological change. Second, we controlled for firm size because larger firms may have richer endowments of resources that enable them to exploit internally- and externally-based R\&D activities. As larger firms are less financially constrained, they are better prepared to assemble resources for innovations. Size was measured as the log of the number of employees. Third, the access of funding from other sources may be correlated to the likelihood of receiving funds from the Spanish government. To mitigate potential biases due to omitting this factor, we considered the variable, other types of subsidies, measured as the log of the total amount of public funds granted by regional and other programs. Fourth, we included the variable, process innovation, to control for the presence of potential complementarities between process and technological innovation and between process and product innovation. To do so, we used a dummy variable that takes the value of 1 any time a firm reported it had process innovations. Finally, we introduced the dummy variable, market structure, which takes the value of 1 when a firm stated that it operated in a market with less than 10 competitors. In doing so, we account for the effects that market concentration may have on either boosting or inhibiting a firm's knowledgesourcing activities and its predisposition to innovate.

Industry-specific characteristics ${ }^{2}$ : First, we incorporated into the analysis the variable industry export intensity, defined as total industrial exports normalized by total industrial sales. On the one hand, firms in industries with a high level of exports may extend their search activities to distinct geographic contexts using their internal and external R\&D activities. On the other hand, firms operating in export industries are likely to innovate more to compete effectively in international markets. Second, we added the variable industrial technological opportunities. Firms operating in industries with a high level of technological opportunities face greater incentives to reinforce their knowledge-sourcing strategies as a way to access such opportunities. The presence of technological opportunities may improve

\footnotetext{
${ }^{2}$ All the variables in this section were measured at two-digit NACE level. For each firm, magnitudes always exclude the corresponding firm-level value. For example, total sales at industry $x$ and for firm i were calculated as follows: total sales in $x$-total sales of firm $i$.
} 
the entire process of technology and product development, affecting a firm's innovation capabilities. We measured technological opportunities as total industry R\&D expenditures normalized by total industry sales. To allow for a non-linear relationship between industrial technological opportunities and firms' innovative performances, on the one hand, and the knowledge-sourcing dimensions on the other, the square of the measure of technological opportunities was also included. Finally, we accounted for the appropriability regime prevailing in each industry. To do so, we followed other studies and built the variable industry appropriability, measured as the ratio of total patents in industry $x$ to total number of companies with patents in industry $x$ (Beneito, 2003). This measure aims to reflect the fact that more patents per innovative company indicate that innovation outcomes in industry $x$ are easy to protect.

\subsection{Methods}

Given our objective of assessing the indirect effect of R\&D subsides on firm innovation running through knowledge sourcing activities, in this study we applied mediation analysis. To accomplish this, we proceed as follows. First, we implemented the Baron and Kenny's (1986) causal-step method for describing the paths through which R\&D subsidies affect the innovation outcomes of supported companies. To define these paths, two sets of models were estimated, one for examining the determinants of a firm's innovative performance and the other for studying the drivers of the knowledge-sourcing dimensions under question. From previous models, we verified the presence of an indirect effect by determining whether (i) public funding for R\&D significantly affects knowledge-sourcing dimensions, and (ii) knowledge-sourcing dimensions determine firms' innovative performance. We also verified the presence of a direct effect of public support for R\&D on firms' innovative performance, once the influence of the mediator variables (i.e., knowledgesourcing dimensions) is controlled. Second, we complemented prior analysis by using a product-coefficient approach (Preacher and Hayes, 2008). In this case, we tested for the statistical significance of the direct and indirect effects attributable to R\&D subsidies. 
It is worthwhile to highlight that the use of mediation analysis has started to grow in recent research on technology-policy evaluation. For instance, some studies have begun to examine the presence of behavioral additionality by using mediation analysis for the identification of intervening mechanisms through which public intervention can affect the way firms learn or form competences (Autio et al., 2008; Knockaert et al., 2014). Other studies use mediation analysis to assess whether internal and/or external R\&D activities are valid channels linking public support for R\&D and innovation outcomes (Kang and Park, 2012; Lee and Wong, 2009).

In the estimation of the models used for our analysis, the potential endogeneity of public support was taken into account. Prior studies on technology-policy evaluation have identified two sources of endogeneity that are relevant for our study (Almus and Czarnitzki, 2003; Busom, 2000; Czarnitzki and Lopes-Bento, 2012; Gelabert et al., 2009). The first source arises from self-selection of firms in the participation stage. This due to the presence of observable and unobservable factors that explain not only firms' incentives to participate in policy programs for promoting R\&D, but also their knowledge-sourcing behavior and innovative performance ${ }^{3}$. Consequently, this fact might generate biases due to the presence of omitted variables that may affect not only participation in R\&D funding programs, but also knowledge sourcing behavior of companies and their innovation outcomes. The second source of endogeneity arises from the selection criteria adopted by the agencies that assign R\&D grants. These agencies can provide support to the more innovative firms or to those with previous experience in knowledge sourcing (called the picking-the-winner effect) as a way to show the effectiveness of their public R\&D funding programs. This issue might result in a reverse causal effect going from innovative performances and knowledge-sourcing behavior to the amount of public R\&D subsidies received by supported companies.

\footnotetext{
${ }^{3}$ For instance, prior studies on technology and innovation show that larger companies and those with experience in R\&D are more likely to undertake knowledge sourcing activities and to face better innovative performance (Almeida et al., 2003; Cassiman and Veugelers, 2006). At the same time, other studies show evidence that companies with these attributes have also a higher propensity to participate in R\&D subsidy programs (Blanes and Busom, 2004).
} 
We attempt to account for the presence of selection biases and reverse causality in several ways. In line with econometric methods established in the literature on technologyevaluation policy (Czarnitzki and Lopes-Bento, 2012; Gelabert et al., 2009; Hussinger, 2008), we took advantages of the panel design of our data using fixed effects specifications to control for the presence of unobserved sources of heterogeneity. As suggested by Gelabert et al. (2009), this strategy attenuates biases resulting from self-selection occurring in the participation stage and from the presence of the picking-the-winner effects ${ }^{4}$. We also used instrumental variables (IV) estimators to address remaining sources of endogeneity of public support. Compared to cross-section matching methods, our approach is not limited to control exclusively for selection on observable variables. Hence, the use of panel data methods and IV estimators does not impose the strong assumption that there is no unobserved factor driving program participation (Czarnitzki and Lopes-Bento, 2012; Hussinger, 2008).

\subsubsection{Models to explain knowledge sourcing dimensions}

We used Tobit regression model ${ }^{5}$ and probit regression analysis to examine the policy -induced effects on internal and external knowledge sourcing, respectively. In both cases, we followed Papke and Wooldridge (2008) and Wooldridge (2002) to treat the presence of endogeneity in the context of these models. Specifically, to account for the presence of timeinvariant unobserved heterogeneity, we implemented the method developed by Chamberlain (1984). In order to allow time-constant omitted factors to be correlated with the covariate under consideration (the controls previously described), the time average of these covariates was included in the estimations. Then, to treat the presence of potential correlation between time-varying omitted factors and our independent variable (public funding for R\&D), we used an instrumental variable estimation approach. The variable foreign capital, measured as the

\footnotetext{
${ }^{4}$ This is the case because firm fixed effects account for unobserved factors that induce firms' knowledge sourcing behavior and innovation performance. Since many of these factors also relate to the firms' propensity to participate in public R\&D funding programs, then the inclusion of fixed effects mitigates selection biases.

${ }^{5} \mathrm{~A}$ Tobit specification is adequate in our context because of the high concentration of observations at the zero value of the variable R\&D effort.
} 
percentage of foreign participation in the share capital of a firm, was taken as an exclusion restriction. We posit that this factor should drive the amount of public R\&D funds a firm receives, but not its knowledge-sourcing behavior. As suggested by González et al.(2005), public agencies prefer to support domestic firms rather than affiliates of foreign-owned companies. Thus, we anticipate a negative relationship between the amount of R\&D funding and the presence of foreign ownership. Moreover, because R\&D adoption choices in the case of subsidiaries of foreign companies are probably taken at the level of their corporate headquarters, it was anticipated that the variable foreign capita/would not significantly affect the knowledge-sourcing strategies of these types of companies.

Finally, we implemented a two-step estimator as follows. In the first-stage, we estimated a pooled Ordinary Least Squares (OLS) regression model in which the public funding for $R \& D$ is regressed on the previously described control variables, the variable foreign capita/and the firm-level average of all the covariates (including the time average of the exclusion restriction). In the second-stage, we estimated a pooled-Tobit model for explaining R\&D effort of firms and pooled probit models for explaining the adoption of openness in innovation strategies. These knowledge-sourcing dimensions are determined by the endogenous variable (public funding for $R \& D$ ), the control variables, the firm-level average of all the covariates, and the residuals corresponding to the first-stage estimation. According to the method developed by Rivers and Vuong (1988), the estimated coefficient of the residuals provides a valid test for the presence of endogeneity in public funds to support R\&D.

\subsubsection{Models to explain firms' innovative performance}

Given the nature of our dependent variables, we used count data analysis to examine the innovation consequences attributable to public R\&D subsidies. Specifically, we implemented a count-panel data model with fixed effects and endogenous covariates. This model was estimated using a Generalized Method of Moments (GMM) estimator with Wooldridge moment conditions (for more details, see Windmeijer, 2000; Wooldridge, 1997). The implemented specification is advantageous for several reasons. First, compared to the 
standard fixed-effects estimator in count-panel data developed by Hausman et al. (1984), the estimator used here provides consistent estimates, even in the presence of non-strict exogenous covariates (Wooldridge, 1997). Second, the treatment of endogeneity is not limited to the public support indicator, but can also be extended to other covariates of the model. By viewing the knowledge-sourcing dimensions as predetermined variables, the model allows consistent estimates of the effects that such dimensions may have on the firm innovative performance to be estimated.

\section{Results}

Table 2 lists the descriptive statistics and bivariate correlations for the variables under question. Reported results reveal no correlation between our measures of firm innovative performance, which is consistent with the idea that patent and new product introduction counts measure different dimensions of the innovation process ${ }^{6}$. Given the existence of moderately high correlations for the case of some pairs of variables, the threat of this issue was assessed by estimating the variance inflation factor (VIF). Furthermore, as a form to mitigate potential multicollinearity, the measure of industrial technological opportunity was centered on its mean before creating its squared term. After doing so, average VIFs for all the covariates were found to be 2.00, with a maximum value of 4.90 in the case of the models explaining the firm innovative performance, and 1.89, with a maximum value of 4.71 , in the case of the models explaining the knowledge-sourcing dimensions. In all the cases, the VIFs were below of the conservative ceiling of 5 .

[Insert Table 2 here]

\subsection{Results from exploring the presence of additionalities}

Before assessing the innovation consequences associated with intermediate effects described above, we examined the presence of additionalities by using a matching approach. Our aim is to determine the average treatment effect on the treated companies (ATT). This requires determining the counterfactual situation for the knowledge sourcing and innovation outcomes that would have been realized if the treatment group (supported companies) had

\footnotetext{
${ }^{6}$ We thank one of our reviewers for highlighting this issue.
} 
not been treated by receiving $R \& D$ subsidies. To do so, we implement the propensity score matching approach proposed by Rosenbaum and Rubin (1983). Once the propensity score has been estimated, we paired each supported company with a single closest non-supported company, using the nearest neighbor matching algorithm. The pairs were chosen based on the similarity in the estimated probabilities of being subsidized. This means that the propensity score comes from a probit estimation on the dummy indicating whether the firm received public support or not. For reason of space, we report only the results concerning the average impact of the National R\&D subsidy program ${ }^{7}$, which is calculated using the ATT. Table 3 presents the comparison of the averages for internal and external knowledge sourcing indicators and for innovation outcomes corresponding to supported companies (treatment group) and non-supported companies (control group).

[Insert Table 3 here]

The results suggest the presence of additionality associated with the public intervention. In terms of input and behavioral additionality, it is observed that supported companies have a higher R\&D effort and propensity to use external knowledge sourcing strategies than non-supported companies. In terms of innovation effects, the results show the presence of output additionality in terms of the patent activity of firms, but not in terms of new product introduction counts. These findings raise two appealing policy question. First, is it possible that part of the direct effect of R\&D subsidies on the firms' patent propensity channels via changes in their knowledge sourcing activities? Second, despite the lack of output additionality, is it possible that R\&D subsidies affect the firms' new product introductions only indirectly through changes in their knowledge sourcing activities? In next section, we present the results of the mediation analysis describe above to assess these policy issues in more details.

\subsection{Results from the causal-step method}

First, we proceed to examine whether public intervention via R\&D subsidies has an

\footnotetext{
${ }^{7}$ Probit results and test of difference between means after matching for the set of covariates used in these estimations are available upon request from the authors.
} 
indirect effect on firm innovation, running through the knowledge sourcing dimensions previously described. According to the causal-step method, an indirect effect can be claimed in our study if (i) R\&D subsidies have a positive and statistically significant effect on the internal and external knowledge sourcing of firms, and (ii) knowledge sourcing activities under consideration have a positive and statistically significant impact on firms' innovative performances. Results reported by Table 4 and 5 are used here to verify these conditions.

The results reported by Table 4 presents the estimations for the Tobit and probit models defining the determinants of the firms' internal and external knowledge sourcing. Estimates in column 1 confirm that R\&D subsidies in Spain positively determine the R\&D effort chosen by firms. This finding is in line with the idea that public R\&D grants lead supported firms to increase their investments in sourcing knowledge through R\&D activities. Columns $2 \mathrm{a}-2 \mathrm{~d}$ report results for the case in which the determinants of each external knowledge-sourcing strategy are considered. Excluding knowledge sourcing from consultants' expertise, the results give support to the premise that R\&D subsidies have a significant effect on increasing firms' propensity to source external knowledge using alternative options. In line with previous studies based on input and behavioral additionality conceptualizations, all these results confirm that public R\&D subsidies generate intermediate effects, according to which firms' R\&D effort and levels of openness in innovation are increased due to the reception of public R\&D subsidies. Notice that these results are consistent those presented by Table 3, in which a matching estimator was used to assess the presence of additionalities.

\section{[Insert Table 4 here]}

Furthermore, the results of the first stage in column 3 show that the estimated parameter of foreign capita/has a negative and statistically significant impact on the amount of public funding for R\&D. This partial correlation gives some support to the validity of this instrument. Moreover, the results in columns 1-2 indicate that reduced-form residuals derived from the first-stage estimate (column 3 ) have a statistically significant effect on all 
the mediating indicators, thus justifying the use of instrumental variables.

The following step consists of assessing whether the induced-effects reported by Table 4 can translate into enhanced innovative performances. Table 5 presents the results for the count-panel data models defining the determinants of the firms' innovative performance, as measured by patent and new product introduction counts, respectively. The estimates in Table 5 were obtained using ExpEnd, a gauss routine for the non-linear GMM estimation of exponential models with endogenous covariates (Windmeijer, 2002). With respect to models determining patent counts, the results correspond to the linear feedback specification as developed by Blundell et al. (2002). This specification accounts for the presence of statistically significant first-order autocorrelation detected in unreported estimates ${ }^{8}$. When using this specification, a first-order correlation is expected to persist, but not a second-order correlation. The results in columns $4 \mathrm{a}$ and $4 \mathrm{~b}$ confirm these requirements, indicating the models are well-specified (Windmeijer, 2002). With respect to models determining new introduction counts, neither first- nor second-order autocorrelation is detected, suggesting these models are well specified ${ }^{9}$.

\section{[Insert Table 5 here]}

The results in columns $4 a$ and $5 a$ provide evidence supporting the presence of a direct effect of public R\&D subsidies on firm innovation, which is consistent with the presence of output additionality in terms of both patent and new product introduction counts. To assess for the presence of indirect effects, we verified whether knowledge sourcing activities shape firm innovation. Estimates in columns $4 b$ and $5 b$ show that the R\&D effort of firms has a positive significant effect on both measures of firm innovative performance. These results give strong support to the idea that intramural R\&D is a mechanism by which firms obtain knowledge required for generating innovations. The implication of this result is

\footnotetext{
${ }^{8}$ Results for the models of patent counts without the lag of the dependent variable are available upon request from the authors.

${ }^{9}$ Consistent with this fact, further experimentation with other specifications shows that the lag in new product introduction counts fails to be statistically significant. Thus, no innovation persistent effects are detected in this case.
} 
that, by leading supported firms to increase their R\&D effort, public intervention in Spain also contributes to enhancing their innovation outcomes. Thus, evidence exists indicating that $R \& D$ subsidies affect firm innovation indirectly, via increments in the R\&D effort of companies.

With regard to the effects of external knowledge-sourcing strategies, the results show that the use of consultants' expertise and the acquisition of knowledge via hiring R\&D employees positively affect both dimensions of firms' innovative performance. We also note that technology cooperation is particularly relevant for inducing product innovation, while knowledge acquisitions in technology markets for inducing technological innovation. Previous results are in line with the idea that knowledge coming from external sources helps companies to enhance their innovations. Nonetheless, our findings also uncover that technology cooperation reduces the firm's patent propensity whereas knowledge acquisitions through technology markets negatively affect the firm's product innovation introductions. Given the relevance of these negative effects, their implications are analyzed in more detailed below in the discussion and conclusion section. From these results, it can be claimed that knowledge acquisitions via the hiring of R\&D personnel are valid channels to realize the benefits of R\&D subsidies on firm innovation. Technology cooperation translates the positive effects of R\&D subsidies only for the case of new product introductions, while the positive mediating role of market-based deals only applies for the case of patent counts. Consultants' expertise fails to channel the impact of R\&D subsidies towards enhanced innovation outcomes given the results of Table 4, which show that R\&D subsidies do not lead companies to source knowledge through this strategy. Finally, we also verify if the direct effects attributable to the presence of output additionality reported in columns $4 a$ and $5 a$ hold once the influence of knowledge sourcing dimensions is controlled. With respect to patents, the results of column $4 \mathrm{~b}$ show that the direct effect of R\&D subsidies keeps positive and statistically significant, revealing that the presence of output additionality remains even after accounting for the intervening role of knowledge sourcing. This finding implies that 
public R\&D subsidies affect a firm's patent activity via a direct effect and via indirect effects, which are channeled through three conduits: (i) an increased R\&D effort, (ii) an enhanced propensity to hiring R\&D personnel, and (iii) augmented possibilities to use technology markets. With respect to new product introductions, the results of column $5 \mathrm{~b}$ uncover that the direct effect of public R\&D subsidies vanishes once the influence of knowledge sourcing is accounted. This result is consistent with the idea that the effect R\&D subsidies on firms' propensity to make new product introductions actually is included in the indirect effect going through their knowledge sourcing activities. An implication of this finding is that R\&D subsidies affect the new product introductions of supported firms only indirectly through three channels: (i) an enhanced R\&D effort, (ii) an increased propensity to form technology cooperation, and (iii) augmented prospects for hiring R\&D personnel.

In the estimation of models in Table 5, lagged values of the covariates measured at firm level were used as valid instruments (see the note following Table 5 for more details). The results also include the Sargan test for over-identifying restrictions, which confirms the validity of the instruments used in the estimations for all cases.

\subsection{Results from the product coefficient method}

To further probe the intervening role of firms' knowledge-sourcing activities, the product coefficient approach was adopted to estimate the direct and indirect effects of R\&D subsidies (Preacher and Hayes, 2004). According to this method, the indirect effect of $X$ on $Y$ mediated by $M_{7}$ and $M_{2}$ is calculated by $\sum_{i} a_{i} \beta_{i}$, where $a_{i}$ is the estimated effect of $X$ on $M_{i}$ while $\beta_{i}$ stands for the estimated effect of $M_{i}$ on $Y$. Estimates for $\alpha_{i}$ and $\beta_{i}$ were obtained from pooled-probit and pooled regression analysis, depending on the nature of the dependent variable. Estimations were conducted by using the Stata routine for Binary Mediation Analysis. From these estimations, we computed point estimates for the indirect and direct effects, along with the corresponding standard errors and test statistics. Then, we generated bootstrap standard errors and $95 \%$ confidence intervals for the population of indirect and 
direct effects ${ }^{10}$. A given effect is viewed as statistically significant if the corresponding confidence interval does not contain a zero. When a zero is included, an insignificance effect is claimed.

Table 6 reports the indirect and direct effects estimated for the case of each measure of innovative performance. In terms of patents, the results confirm that the direct effect of R\&D subsidies is positive and statistically significant, which is consistent with the presence of output additionality. In addition, there is evidence indicating the presence of the indirect effect of R\&D subsidies running through the firms' R\&D effort and from knowledge acquisitions occurring via technology markets, the hiring of R\&D personnel and consultants' expertise. The indirect effect going through the firms' R\&D effort is remarkably strong, compared to those going through the external knowledge sourcing activities. The results also confirm R\&D subsidies have a negative indirect effect running through technology cooperation. For this case, the direct effect seems substantial being approximately $78 \%$ of the total effect attributable to public R\&D subsidies. In contrast, the indirect effects running by internal and external knowledge sourcing strategies represent nearly $22 \%$ of the total effect produced by the public intervention.

In terms of new product introductions, the results confirm the absence of a direct effect, given that the $95 \%$ confidence interval for the direct effect includes a zero. This reveals that R\&D subsidies only affect firms' propensity to make new product introductions exclusively through inducing increments in the knowledge sourcing activities of supported companies. The results indicate that the indirect effects transmitted via the firms' R\&D effort and the use of technology cooperation deals predominate to enhance new product introductions. Compared to the results reported from the casual step method, some differences exist regarding the mediating role of the external knowledge sourcing strategies. According to the product coefficient approach, the indirect effects running via technology markets is positive and statistically significant, while that running through labor markets fails

\footnotetext{
${ }^{10}$ For instance, compared to the Sobel test, this strategy is advantageous because it does not impose any assumption on the distribution of the indirect effects (Preacher and Hayes, 2008).
} 
to be statistically significant, as indicated by the inclusion of a zero in the $95 \%$ confidence interval.

\section{[Insert Table 6 here]}

\section{Discussion and conclusions}

This study assesses the impact of public intervention through R\&D subsidies on firm innovation. In the evaluation of this policy scheme, the focus has been on assessing whether the induced changes in the knowledge sourcing of supported companies contribute to enhancing their innovation outcomes. In particular, the knowledge sourcing of firm has been defined by (i) the R\&D effort it chooses, and (ii) the degree of openness it applies for its innovations. By using panel data for Spanish manufacturing companies during the period 1998-2005, the study is among the first in determining if the impact of R\&D subsidies on increasing companies' R\&D effort and levels of openness in innovation further translates into enhanced innovation outcomes, measured as patent applications and new product counts.

The results of the study strongly support the premise that the intermediate effects of public R\&D subsidies on the knowledge sourcing of firms also contribute to enhancing their innovation outcomes. In terms of patent counts, the study shows that public support via R\&D subsidies has a direct effect, which is in line with previous studies on output additionality (Cappelen et al., 2012; Czarnitzki and Licht, 2006). A more subtle indirect effect is found, which runs largely through an enhancement of the R\&D effort of the recipient companies. A smaller indirect effect also exists, going from the public intervention to patent counts via the use of technology and labor markets. Weaker evidence also indicates that the use of consultants' expertise mediates the link between public R\&D subsides and firms' patent activity. These results show that a part of the total impact of R\&D subsidies on boosting the patent activities of supported firms corresponds to indirect effects running through increments in their internal and external knowledge sourcing activities. In terms of new product introduction counts, the study shows the absence of output additionality, once the effect of the knowledge sourcing dimensions under consideration are controlled. This finding 
has important implications for the evaluation of R\&D subsidies. It indicates that public R\&D subsidies affect firms' capacity to make new product introductions only indirectly by inducing increments in their internal and external knowledge sourcing activities. More specifically, public intervention via R\&D subsidies brings new product introductions by increasing firms' R\&D effort and use of technology cooperation. Weaker evidence also is reported that policy-induced increments in the use of consultants' expertise contribute to enhancing the new product counts of supported firms. Results with respect to the presence of intermediate effects running through technology and labor markets are not conclusive in this case.

One important contribution of our study is to show that the classical effects of public intervention on input and behavior additionality also have an impact on firms' innovative performances. Our results are in line with those reported by Czarnitzki and Licht (2006) and Hussinger (2008) that public intervention has a direct effect on firms' innovations and an indirect effect that transmits through policy-induced increases in the firms' R\&D. However, our research extends these contributions by evaluating not only the indirect effects running via the R\&D effort of firms, but also those being transmitted by external knowledge sourcing strategies, such as technology cooperation, technology markets and the hiring of R\&D personnel. Our finding also complement those reported by Kang and Park (2012) that R\&D resources and inter-firm alliances mediate the link between government R\&D support and firms innovation. Our study advances this contribution by evaluating the impact of public support for R\&D on alternative dimensions of firm innovation (i.e., patent and new product counts). As indicated by our results, the intensity of the direct and indirect effects may depend on the innovation outcome being analyzed. While patents are an intermediate output within the innovation process, it is expected that the direct effects of R\&D resources and collaboration links on the patenting activity of firms are stronger, compared to those affecting more marketable indicators like new product introductions. Finally, our results confirm the results of Lee and Wong (2009) that R\&D collaboration is a linking mechanism 
translating the effect of government support for R\&D into an enhanced propensity of firms to make new product innovations. Nonetheless, our research offers a more integrative evaluation perspective, in which the indirect effect transmitted via policy-induced increments in firms' intramural R\&D activities is also considered.

Another important contribution of our research is that it challenges the implicit assumption on studies of technology-policy evaluation that the intermediate effects attributable to input and behavioral additionality are for the better. For instance, our study uncovers negative indirect effects of R\&D subsidies on the patent activity and new product introductions of supported companies, which are attributable to increments in technology cooperation and knowledge acquisitions in technology markets, respectively. In the case of technology cooperation, the fear of partners to leak strategic information to others during the invention process might lead them to restrict their interactions (Arora et al., 2004; Laursen and Salter, 2006). This fact would impede knowledge sharing within technology cooperation, thus affecting the production of knowledge in terms of patents. In the case knowledge sourced from technology markets, it seems that it contributes more to solving technical and engineering problems within the technology and product development process than to improving the introduction of new products. Altogether, these findings highlight the importance of making technology policy evaluation not only by considering the input and behavioral additionality derived from public interventions, but also by including the innovation consequences associated with these intermediate effects.

\subsection{Implications}

The findings of this study have relevance for both innovation policy and innovation management. As regards innovation policy, this study shows that the effectiveness of public intervention in enhancing firm innovation depends critically on the induced effect of the intervention on the knowledge sourcing of recipient firms. Thus, programs that improve the acquisition of external problem-solving capabilities (within and outside firms' organizational boundaries) may result in further innovations. For instance, policies that improve the 
efficiency of the markets for technology (e.g., developing intellectual property right systems), promote cooperation (e.g., founding of R\&D consortia) or enable mobility of knowledge workers among private and public institutions may help firms enhance the degree of openness of their innovation. In doing so, these policies also contribute to extending the technological space from which firms draw solutions for their innovation problems, thus favoring the generation of technology and product innovations. Similarly, polices permitting firms to develop their human resources (e.g., technical training programs) may facilitate the undertaking of knowledge sourcing through in-house R\&D and then grasp the potential benefits of public intervention. These suggestions inform innovation policy makers by indicating that important complementarities may exist between alternative policy instruments. For instance, the contribution of R\&D subsidies to promoting firm innovation may increase if policies promoting the use of open innovation models in firms are also applied. An implication of this fact is that innovation policy combining several schemes may correct not only market failures (underinvestment in R\&D), but also system failures (lack of connectivity across organizations). In addition, our results indicate that the objectives of public intervention also gain relevance. When the final goal is to enhance firms' inventiveness, programs that stimulate technology cooperation could be counterproductive. Public intervention aimed at improving the appropriability regime faced by supported firms might reduce the fear of leakages of strategy information during $R \& D$ collaborations, thus favoring the presence of positive innovation effects in terms of patent counts.

As regards innovation management, this study shows that knowledge sourcing allows supported companies to harness the resources received from R\&D funding programs. An implication of this fact is that supported firms' strategies that improve knowledgesourcing will also contribute to grasping the potential benefits of public intervention. This idea is in line with the work of Wong and He (2003), who show that public R\&D support is more effective when firms create an internal culture for innovation. Likewise, strategies stimulating the use of open innovation models, namely, the use of information technologies, 
cross-functional teams, and incentives based on open-orientated metrics, may further lead firms to leverage their knowledge-sourcing activities, thus favoring the realization of the benefits of public support for R\&D.

\subsection{Limitations and extensions}

The results of this study are subject to some limitations and, at the same time, open new directions for future research. First, given data restrictions, the study infers firms' knowledge-sourcing behavior by using the observable results associated with such behavior. This prevents examination of specific behaviors in knowledge sourcing that are induced by public intervention. In terms of the Gök and Edler (2012) approach of behavior additionality, our operationalization of knowledge sourcing remains simple and only encompasses the scale, scope and openness dimensions of supported firms' R\&D behavior. Thus, it is recognized that more research is needed to identify specific behavior patterns in knowledge sourcing that arise from public intervention. Second, we have sustained that the presence of "experience effects" and "technological opportunities" associated with publicly funded R\&D projects are mechanisms that drive public intervention to shape the knowledge-sourcing behavior of supported firms, but we have not measured them directly. In line with Clarysse et al. (2009), future research should attempt to measure these latent variables that favor behavioral changes in the knowledge-sourcing activities of supported companies. Third, despite the use of panel data techniques, the study does not treat the issue of the time scale needed to observe the effects of public intervention. Hence, long-term effects induced by R\&D grants are not entirely considered. Additional research is required to identify the time span needed to observe the indirect effects of R\&D grants on firm innovation that include knowledge sourcing. Fourth, although our mediated model provides an integrative approach to assess the impact of intermediate effects of public intervention on innovation outcomes, our model remains incomplete because it does not consider resulting effects on variables measuring commercial success, such as revenues for out-licensing, sales growth, or market value. Future research is needed to complete the link between firm innovative performance 
and other dimensions of firm performance.

\section{References}

Afcha, S., 2011. Behavioural additionality in the context of regional innovation policy in Spain. Innov. Manag. Policy Pract. 13, 95-110.

Ahuja, G., 2000. Collaboration networks, structural holes, and innovation: A longitudinal study. Adm. Sci. Q. 45, 425-455.

Almeida, P., Dokko, G., Rosenkopf, L., 2003. Startup size and the mechanisms of external learning: increasing opportunity and decreasing ability? Res. Policy 32, 301-315.

Almus, M., Czarnitzki, D., 2003. The effects of public R\&D subsidies on firms' innovation activities. J. Bus. Econ. Stat. 21, 226-236.

Arora, A., Fosfuri, A., Gambardella, A., 2004. Markets for technology: The economics of innovation and corporate strategy. The MIT Press, Cambridge Massachusetts.

Arrow, K., 1962. Economic welfare and the allocation of resources for invention, in: Nelson, R. (Ed.), The Rate and Direction of Inventive Activity: Economic and Social Factors. Princeton University Press, New Jersey, pp. 609-625.

Autio, E., Kanninen, S., Gustafsson, R., 2008. First-and second-order additionality and learning outcomes in collaborative R\&D programs. Res. Policy 37, 59-76.

Ballesteros, J.A., Rico, A.M., 2001. Public financing of cooperative R\&D projects in Spain: the Concerted Projects under the National R\&D Plan. Res. Policy 30, 625-641.

Banbury, C.M., Mitchell, W., 1995. The effect of introducing important incremental innovations on market share and business survival. Strateg. Manag. J. 16, 161-182. doi:10.1002/smj.4250160922

Baron, R.M., Kenny, D.A., 1986. The moderator-mediator variable distinction in social psychological research: Conceptual, strategic, and statistical considerations. J. Pers. Soc. Psychol. 51, 1173-1182.

Beneito, P., 2003. Choosing among alternative technological strategies: an empirical analysis of formal sources of innovation. Res. Policy 32, 693-713.

Bérubé, C., Mohnen, P., 2009. Are firms that receive R\&D subsidies more innovative? Can. J. Econ. Can. d'économique 42, 206-225.

Blanes, J. V, Busom, I., 2004. Who participates in R\&D subsidy programs?: The case of Spanish manufacturing firms. Res. Policy 33, 1459-1476.

Blundell, R., Griffith, R., Reenen, J. Van, 1995. Dynamic count data models of technological innovation. Econ. J. 105, 333-344.

Blundell, R., Griffith, R., Windmeijer, F., 2002. Individual effects and dynamics in count data models. J. Econom. 108, 113-131.

Buisseret, T.J., Cameron, H.M., Georghiou, L., 1995. What difference does it make additionality in the public support of R\&D in large firms. Int. J. Technol. Manag. 10, 4-5.

Busom, I., 2000. An empirical evaluation of the effects of R\&D subsidies. Econ. Innov. New Technol. 9, 111-148.

Busom, I., Fernández-Ribas, A., 2008. The impact of firm participation in R\&D programmes on R\&D partnerships. Res. Policy 37, 240-257.

Cappelen, Å., Raknerud, A., Rybalka, M., 2012. The effects of R\&D tax credits on patenting and innovations. Res. Policy 41, 334-345. doi:10.1016/j.respol.2011.10.001

Cassiman, B., Veugelers, R., 2006. In search of complementarity in innovation strategy: internal R\&D and external knowledge acquisition. Manage. Sci. 52, 68-82. 
Chamberlain, G., 1984. Panel data, in: Griliches, Z., Intilligator, M. (Eds.), Handbook of Econometrics. Elsvier, North Holland, Amsterdam, The Netherlands, pp. 1247-1318.

Chesbrough, H., 2006. Open innovation: The new imperative for creating and profiting from technology. Harvard Business Press, Boston MA.

Cincera, M., 1997. Patents, R\&D, and technological spillovers at the firm level: Some evidence from econometric count models for panel data. J. Appl. Econom. 12, 265-280.

Clarysse, B., Wright, M., Mustar, P., 2009. Behavioural additionality of R\&D subsidies: A learning perspective. Res. Policy 38, 1517-1533.

Cohen, W., Levinthal, D., 1990. Absorptive capacity: a new perspective on learning and innovation. Adm. Sci. Q. 35, 128-152.

COTEC, 2007. Tecnología e Innovación en España: Informe Cotec 2007.

Czarnitzki, D., Ebersberger, B., Fier, A., 2007. The relationship between R\&D collaboration, subsidies and R\&D performance: Empirical evidence from Finland and Germany. J. Appl. Econom. 22, 1347-1366.

Czarnitzki, D., Licht, G., 2006. Additionality of public R\&D grants in a transition economy. Econ. Transit. 14, 101-131.

Czarnitzki, D., Lopes-Bento, C., 2012. Value for money? New microeconometric evidence on public R\&D grants in Flanders. Res. Policy 42, 76-89.

David, P.A., Hall, B.H., Toole, A.A., 2000. Is public R\&D a complement or substitute for private R\&D? A review of the econometric evidence. Res. Policy 29, 497-529. doi:10.1016/S0048-7333(99)00087-6

Duguet, E., 2004. Are R\&D subsidies a substitute or a complement to privately funded RaD? Rev. Econ. Polit. 114, 245-274.

Falk, R., 2007. Measuring the effects of public support schemes on firms' innovation activities: Survey evidence from Austria. Res. Policy 36, 665-679.

Fleming, L., Sorenson, O., 2001. Technology as a complex adaptive system: Evidence from patent data. Res. Policy 30, 1019-1039.

Gelabert, L., Fosfuri, A., Tribó“, J., 2009. Does the effect of public support for R\&D depend on the degree of appropriability? J. Ind. Econ. 57, 736-767. doi:10.1111/j.14676451.2009.00396.x

Georghiou, L., Clarysse, B., Steurs, G., Bilsen, V., Larosse, J., 2004. Making the difference: The evaluation of behavioural additionality of R\&D subsidies (No. IWT-STUDIES 48, June).

Gök, A., Edler, J., 2012. The use of behavioural additionality evaluation in innovation policy making. Res. Eval. 21, 306-318.

Gomes-Casseres, B., Hagedoorn, J., Jaffe, A.B., 2006. Do alliances promote knowledge flows? J. financ. econ. 80, 5-33.

González, X., Jaumandreu, J., Pazó, C., 2005. Barriers to innovation and subsidy effectiveness. RAND J. Econ. 36, 930-950.

Grant, R.M., Baden-Fuller, C., 2004. A Knowledge accessing theory of strategic alliances. J. Manag. Stud. 41, 61-84.

Griliches, Z., 1991. Patent statistics as economic indicators: a survey. J. Econ. Lit. 28, 1661-1707.

Hausman, J., Hall, B., Griliches, Z., 1984. Econometric Models for Count Data with an Application to the Patents-R\&D Relationship. Econometrica 52, 909-938.

Helfat, C.E., 1994. Evolutionary Trajectories in Petroleum Firm R\&D. Manage. Sci. doi:10.1287/mnsc.40.12.1720 
Hess, A.M., Rothaermel, F.T., 2011. When are assets complementary? Star scientists, strategic alliances, and innovation in the pharmaceutical industry. Strateg. Manag. J. 32, 895-909.

Hewitt-Dundas, N., Roper, S., 2010. Output additionality of public support for innovation: evidence for Irish manufacturing plants. Eur. Plan. Stud. 18, 107-122.

Huergo, E., Trenado, M., 2010. The application for and the awarding of low-interest credits to finance R\&D projects. Rev. Ind. Organ. 37, 237-259.

Hujer, R., Radić, D., 2005. Evaluating the impacts of subsidies on innovation activities in Germany. Scott. J. Polit. Econ. 52, 565-586.

Hussinger, K., 2008. R\&D and subsidies at the firm level: An application of parametric and semiparametric two-step selection models. J. Appl. Econom. 23, 729-747.

Kang, K.N., Park, H., 2012. Influence of government R\&D support and inter-firm collaborations on innovation in Korean biotechnology SMEs. Technovation 32, 68-78.

Katila, R., Ahuja, G., 2002. Something old, something new: A longitudinal study of search behavior and new product introduction. Acad. Manag. J. 45, 1183-1194.

Katila, R., Chen, E.L., 2008. Effects of search timing on innovation: The value of not being in Sync with rivals. Adm. Sci. Q. 53, 593-625.

Klette, T.J., Møen, J., Griliches, Z., 2000. Do subsidies to commercial R\&D reduce market failures? Microeconometric evaluation studies. Res. Policy 29, 471-495.

Klevorick, A.K., Levin, R.C., Nelson, R.R., Winter, S.G., 1995. On the sources and significance of interindustry differences in technological opportunities. Res. Policy 24, 185-205. doi:10.1016/0048-7333(93)00762-I

Knockaert, M., Spithoven, A., Clarysse, B., 2014. The impact of technology intermediaries on firm cognitive capacity additionality. Technol. Forecast. Soc. Change 81, 376-387. doi:10.1016/j.techfore.2013.05.007

Lakhani, K., Lifshitz-Assaf, H., Tushman, M., 2013. Open innovation and organizational boundaries: The impact of task decomposition and knowledge distribution on the locus of innovation, in: Grandori, A. (Ed.), Handbook of Economic Organization: Integrating Economic and Organization Theory. Edward Elgar, pp. 355-382.

Laursen, K., Leone, M.I., Torrisi, S., 2010. Technological exploration through licensing: new insights from the licensee's point of view. Ind. Corp. Chang. 19, 871-897. doi:10.1093/icc/dtq034

Laursen, K., Salter, A., 2006. Open for innovation: the role of openness in explaining innovation performance among UK manufacturing firms. Strateg. Manag. J. 27, 131-150.

Lee, C., 2011. The differential effects of public R\&D support on firm R\&D: Theory and evidence from multi-country data. Technovation 31, 256-269.

Lee, L., Wong, P., 2009. Firms' Innovative Performance: The Mediating Role of Innovative Collaborations (No. 16193), MPRA Paper.

Leuven, E., Sianesi, B., 2003. Stata module to perform full Mahalanobis and propensity score matching, common support graphing, and covariate imbalance testing. Stat. Softw. Components S 432001.

Mairesse, J., Mohnen, P., 2010. Using innovations surveys for econometric analysis, in: Hall, B., Rosenberg, N. (Eds.), Handbook of the Economics of Innovation. Elsevier B.V, pp. 733-1256.

Mohnen, P., Hoareau, C., 2003. What type of enterprise forges close links with universities and government labs? Evidence from CIS 2. Manag. Decis. Econ. 24, 133-145. 
doi:10.1002/mde.1086

Montalvo, J.G., 1997. GMM estimation of count-panel-data models with fixed effects and predetermined instruments. J. Bus. Econ. Stat. 15, 82-89.

Mowery, D.C., Oxley, J.E., Silverman, B.S., 1996. Strategic alliances and interfirm knowledge transfer. Strateg. Manag. J. 17, 77-91.

Nerkar, A., 2003. Old is gold? The value of temporal exploration in the creation of new knowledge. Manage. Sci. 49, 211-229.

Nerkar, A., Roberts, P.W., 2004. Technological and product-market experience and the success of new product introductions in the pharmaceutical industry. Strateg. Manag. J. 25, 779-799. doi:10.1002/smj.417

OECD, 2005. Oslo Manual:Guidelines for Collecting and Interpreting Innovation Data. OECD Editions, Paris.

Papke, L., Wooldridge, J., 2008. Panel data methods for fractional response variables with an application to test pass rates. J. Econom. 145, 121-133.

Phelps, C.C., 2010. A Longitudinal Study of the Influence of Alliance Network Structure and Composition on Firm Exploratory Innovation. Acad. Manag. J. 53, 890-913. doi:10.5465/AMJ.2010.52814627

Pisano, G., 2000. In search of dynamic capabilities: The origin of capabilities in biopharmaceuticals, in: Dosi, G., Nelson, R., Winter, S. (Eds.), The Nature and Dynamics of Organizational Capabilities. Oxford University Press, New York, pp. 129-154.

Powell, W., Koput, K., Smith-Doerr, L., 1996. Interorganizational collaboration and the locus of innovation: Networks of learning in biotechnology. Adm. Sci. Q. 41, 116-145.

Preacher, K.J., Hayes, A.F., 2004. SPSS and SAS procedures for estimating indirect effects in simple mediation models. Behav. Res. Methods, Instruments, Comput. 36, 717-731. doi:10.3758/BF03206553

Preacher, K.J., Hayes, A.F., 2008. Asymptotic and resampling strategies for assessing and comparing indirect effects in multiple mediator models. Behav. Res. Methods 40, 879-891. doi:10.3758/BRM.40.3.879

Rivers, D., Vuong, Q., 1988. Limited Information Estimators and Exogeneity Tests for Simultaneous Profit Models. J. Econom. 39, 347-366.

Roper, S., Hewitt-Dundas, N., 2012. Does additionality persist? A panel data investigation of the legacy effects of public support for innovation (No. Paper presented at the 2012 DRUID Summer Conference). Copenhagen.

Roper, S., Hewitt-Dundas, N., Love, J.H., 2004. An ex ante evaluation framework for the regional benefits of publicly supported R\&D projects. Res. Policy 33, 487-509.

Rosenbaum, P., Rubin, D., 1983. The central role of the propensity score in observational studies for causal effects. Biometrika 70, 41-55.

Rosenkopf, L., Nerkar, A., 2001. Beyond local search: boundary-spanning, exploration, and impact in the optical disk industry. Strateg. Manag. J. 22, 287-306.

Rothaermel, F., Alexandre, M., 2009. Ambidexterity in technology sourcing: The moderating role of absorptive capacity. Organ. Sci. 20, 759-780.

Salomon, R.M., Shaver, J.M., 2005. Learning by exporting: new insights from examining firm innovation. J. Econ. Manag. Strateg. 14, 431-460.

Santamaria, L., Jesus Nieto, M., Barge-Gil, A., 2010. The Relevance of Different Open Innovation Strategies for R\&D Performers. Cuad. Econ. y Dir. la Empres. 13, 93-114. doi:10.1016/S1138-5758(10)70025-6 
Scherer, F., 1983. R\&D and Declining Productivity Growth. Am. Econ. Rev. 73, 215-218.

Schilling, M., 2012. Strategic Management of Technological Innovation:, 2nd ed. ed. McGrawHill, Boston MA.

Schilling, M., Hill, C., 1998. Managing the new product development process: strategic imperatives. Acad. Manag. Exec. 12,67-81.

Segarra-Blasco, A., Arauzo-Carod, J.-M., 2008. Sources of innovation and industry-university interaction: Evidence from Spanish firms. Res. Policy 37, 1283-1295. doi:10.1016/j.respol.2008.05.003

Sidhu, J., Commandeur, H., Volberda, H., 2007. The multifaceted nature of exploration and exploitation: Value of supply, demand, and spatial search for innovation. Organ. Sci. 18, 20-38.

Vega-Jurado, J., Gutiérrez-Gracia, A., Fernández-de-Lucio, I., 2009. Does external knowledge sourcing matter for innovation? Evidence from the Spanish manufacturing industry. Ind. Corp. Chang. 18, 637-670.

Wanzenböck, I., Scherngell, T., Fischer, M.M., 2013. How do firm characteristics affect behavioural additionalities of public R\&D subsidies? Evidence for the Austrian transport sector. Technovation 33, 66-77. doi:10.1016/j.technovation.2012.11.006

West, J., Bogers, M., 2014. Leveraging External Sources of Innovation: A Review of Research on Open Innovation. J. Prod. Innov. Manag. 31, 814-831. doi:10.1111/jpim.12125

Windmeijer, F., 2000. Moment conditions for fixed effects count data models with endogenous regressors. Econ. Lett. 68, 21-24.

Windmeijer, F., 2002. ExpEnd, Gauss programme for non-linear GMM estimation of EXPonential models with ENDogenous regressors for cross-section and panel data (No. CWP14/02), Cemmap Working Paper.

Wong, P.K., He, Z.L., 2003. The moderating effect of a firm's internal climate for innovation on the impact of public R\&D support programmes. Int. J. Entrep. Innov. Manag. 3, 525-545.

Wooldridge, J.M., 1997. Multiplicative panel data models without the strict exogeneity assumption. Econom. Theory 13,667-678.

Wooldridge Jeffrey, M., 2002. Econometric analysis of cross section and panel data. The MIT Press, Cambridge Massachusetts.

Figure 1. Model Explaining the Links between the R\&D Subsidies and the Firms' Innovative performance 


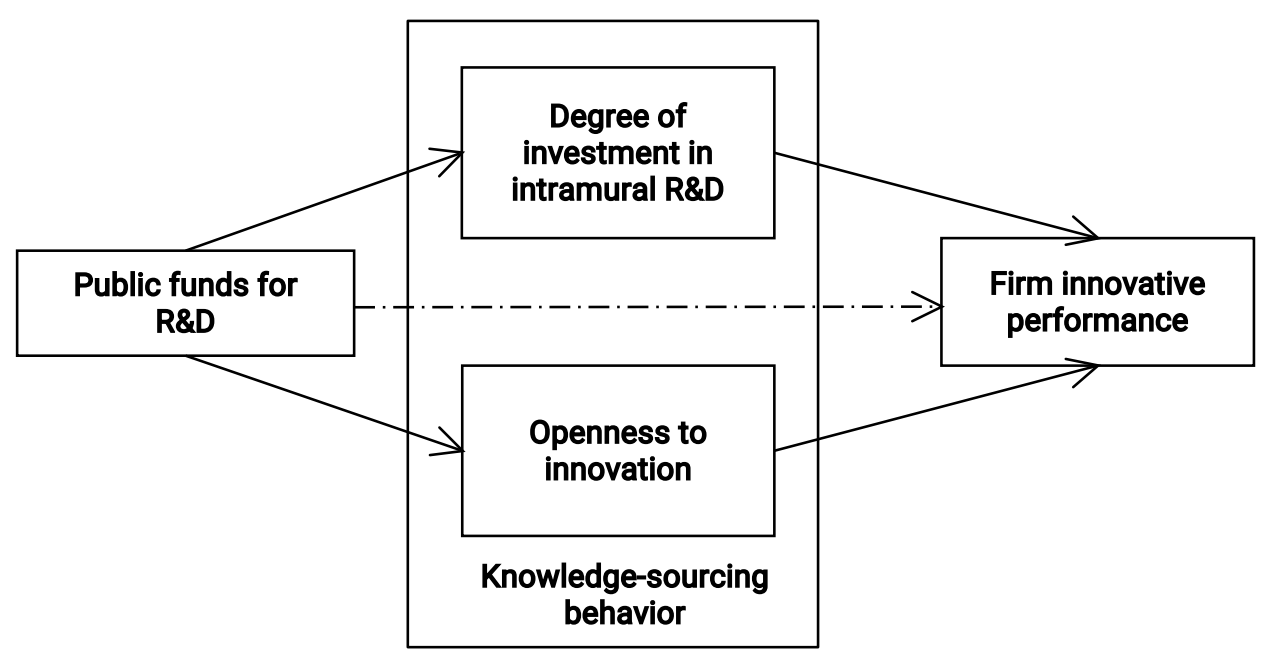

Table 1. Percentage of Firms by Type of Industry, Size and Support Status

\begin{tabular}{ccccccc}
\hline \multirow{2}{*}{ Year } & \multicolumn{2}{c}{ Low-intensive tech industries } & & \multicolumn{2}{c}{ High-intensive tech industries } \\
\cline { 2 - 3 } \cline { 5 - 6 } \cline { 5 - 6 } $\mathbf{2 0 0}$ Workers & With subsidies & & \multicolumn{3}{|c|}{$\mathbf{2 0 0}$ Workers } & With subsidies \\
\hline 1998 & 48.6 & 19.5 & & 85.7 & 20.8 \\
1999 & 48.9 & 18.1 & & 85.3 & 27.7 \\
2000 & 48.6 & 21.3 & & 87.4 & 21.3 \\
2001 & 50.0 & 17.9 & & 88.4 & 24.4 \\
2002 & 49.9 & 15.3 & & 90.2 & 25.0 \\
2003 & 50.6 & 15.3 & & 89.2 & 20.3 \\
2004 & 50.8 & 9.2 & & 89.4 & 24.6 \\
2005 & 51.0 & 12.3 & & 90.1 & 12.3 \\
\hline
\end{tabular}


Table 2. Descriptive Statistics and Pairwise Correlations

\begin{tabular}{|c|c|c|c|c|c|c|c|c|c|c|c|c|c|c|c|c|c|c|}
\hline \multicolumn{2}{|c|}{ Variables } & Mean & SD & Min & \multirow{2}{*}{\multicolumn{2}{|c|}{$\begin{array}{c}\text { Max } \\
158\end{array}$}} & \multirow{2}{*}{$\begin{array}{c}1 \\
1.00\end{array}$} & \multirow[t]{2}{*}{2} & \multirow[t]{2}{*}{3} & \multirow[t]{2}{*}{4} & \multirow[t]{2}{*}{5} & \multirow[t]{2}{*}{6} & \multirow[t]{2}{*}{7} & \multirow[t]{2}{*}{8} & \multirow[t]{2}{*}{9} & \multirow[t]{2}{*}{10} & \multirow[t]{2}{*}{11} & \multirow[t]{2}{*}{12} \\
\hline 1 & Patent applications & 0.42 & 4.68 & 0 & & & & & & & & & & & & & & \\
\hline 2 & New product introductions & 1.81 & 11.74 & 0 & 42 & & 0.00 & 1.00 & & & & & & & & & & \\
\hline 3 & Technology cooperation & 0.29 & 0.45 & 0 & 1 & & 0.10 & 0.08 & 1.00 & & & & & & & & & \\
\hline 4 & Labor markets & 0.26 & 0.44 & 0 & 1 & & 0.10 & 0.06 & 0.49 & 1.00 & & & & & & & & \\
\hline 5 & Markets for technology & 0.25 & 0.43 & 0 & 1 & & 0.12 & 0.08 & 0.59 & 0.39 & 1.00 & & & & & & & \\
\hline 6 & Consultants' expertise & 0.21 & 0.41 & 0 & 1 & & 0.11 & 0.06 & 0.44 & 0.36 & 0.37 & 1.00 & & & & & & \\
\hline 7 & R\&D effort & 0.45 & 1.63 & 0 & 50. & & 0.22 & 0.09 & 0.34 & 0.25 & 0.27 & 0.16 & 1.00 & & & & & \\
\hline 8 & Public funding for R\&D & 93.64 & $\begin{array}{c}1,926.8 \\
5\end{array}$ & 0 & 98,3 & & 0.06 & 0.00 & 0.08 & 0.08 & 0.08 & 0.02 & 0.20 & 1.00 & & & & \\
\hline 9 & Technological assessment & 0.32 & 0.47 & 0 & 1 & & 0.09 & 0.07 & 0.50 & 0.42 & 0.36 & 0.60 & 0.23 & 0.07 & 1.00 & & & \\
\hline 10 & Firm size & $\begin{array}{c}202.4 \\
4\end{array}$ & 555.39 & 2 & 12,9 & & 0.10 & 0.03 & 0.29 & 0.30 & 0.30 & 0.20 & 0.15 & 0.35 & 0.22 & 1.00 & & \\
\hline 11 & Other type of subsidies & 16.07 & 170.17 & 0 & 5,15 & & 0.01 & 0.01 & 0.14 & 0.14 & 0.15 & 0.09 & 0.17 & 0.23 & 0.12 & 0.43 & 1.00 & \\
\hline 12 & Process innovation & 0.70 & 0.46 & 0 & 1 & & -0.06 & -0.09 & -0.33 & -0.29 & -0.26 & -0.27 & -0.13 & -0.03 & -0.32 & -0.16 & -0.09 & 1.00 \\
\hline 13 & Industry export intensity & 28.44 & 13.90 & 2.91 & 66. & & 0.01 & 0.01 & 0.16 & 0.17 & 0.16 & 0.07 & 0.11 & 0.06 & 0.11 & 0.15 & 0.11 & 0.01 \\
\hline 14 & Market structure & 0.56 & 0.50 & 0 & 1 & & 0.00 & 0.02 & 0.19 & 0.17 & 0.20 & 0.12 & 0.06 & 0.03 & 0.16 & 0.14 & 0.06 & 0.00 \\
\hline 15 & Ind. tech opportunities ${ }^{*}$ & 0.63 & 0.82 & 0.01 & 7.4 & & 0.04 & 0.00 & 0.16 & 0.18 & 0.17 & 0.05 & 0.21 & 0.11 & 0.10 & 0.08 & 0.15 & 0.04 \\
\hline 16 & $\begin{array}{l}\text { Ind. tech opportunities } \\
\text { squared }^{*}\end{array}$ & 1.06 & 4.05 & 0.00 & 55. & & 0.02 & 0.00 & 0.10 & 0.13 & 0.11 & 0.03 & 0.13 & 0.09 & 0.07 & 0.08 & 0.15 & 0.02 \\
\hline 17 & Industry appropriability & 3.05 & 1.34 & 0 & 6.7 & & 0.07 & 0.00 & 0.14 & 0.12 & 0.12 & 0.04 & 0.14 & 0.00 & 0.06 & 0.03 & 0.02 & 0.07 \\
\hline 18 & Foreign capital & 16.95 & 36.27 & 0 & 10 & & 0.00 & 0.04 & 0.28 & 0.29 & 0.32 & 0.11 & 0.08 & 0.06 & 0.18 & 0.28 & 0.07 & 0.00 \\
\hline Vari & ables & 13 & 14 & 15 & 16 & 17 & $1 \varepsilon$ & & & & & & & & & & & \\
\hline 13 & Industry export intensity & 1.00 & & & & & & & & & & & & & & & & \\
\hline 14 & Market structure & -0.10 & 1.00 & & & & & & & & & & & & & & & \\
\hline 15 & Ind. tech opportunities ${ }^{*}$ & -0.12 & 0.02 & 1.00 & & & & & & & & & & & & & & \\
\hline 16 & $\begin{array}{l}\text { Ind. tech opportunities } \\
\text { squared }^{*}\end{array}$ & -0.04 & 0.33 & 0.06 & 1.00 & & & & & & & & & & & & & \\
\hline 17 & Industry appropriability ${ }^{\S}$ & -0.03 & 0.26 & 0.05 & 0.91 & 1.00 & & & & & & & & & & & & \\
\hline 18 & Foreign capital & -0.06 & 0.28 & 0.03 & 0.25 & 0.0 & 1.0 & & & & & & & & & & & \\
\hline
\end{tabular}


Table 3. Impact of National R\&D Subsidies on Internal and External Knowledge Sources and on Innovative Outcomes

\begin{tabular}{|c|c|c|c|c|c|}
\hline Variable & Treated & Controls & Difference & S.E. & T-stat \\
\hline R\&D effort & 2.71 & 1.99 & 0.72 & 0.26 & $2.75^{\star \star \star}$ \\
\hline Technology cooperation & 0.97 & 0.87 & 0.10 & 0.03 & $2.94^{\star \star \star}$ \\
\hline Labor markets & 0.87 & 0.78 & 0.10 & 0.04 & $2.27^{\star \star}$ \\
\hline Markets for technology & 0.78 & 0.69 & 0.09 & 0.05 & $2.03^{\star \star}$ \\
\hline Consultants' expertise & 0.63 & 0.57 & 0.06 & 0.05 & 1.33 \\
\hline Number of patents & 3.63 & 2.26 & 1.37 & 1.08 & 1.27 \\
\hline New product introductions & 4.01 & 3.02 & 0.99 & 1.09 & 0.91 \\
\hline
\end{tabular}

Notes. (i) Matching and average treatment effects were performed following Leuven and Sianesi (2003) psmatch2 Stata module.

(ii) The following variables were used in the probit model estimation that serves a base for the matching: Regional subsidies

(0,1 dummy), Subsidies for other organisms ( 0,1 dummy), R\&D expenditures in $\mathrm{t}-1$ (in Euros), National public subsidies in t- 1 (0,1 dummy), Technology cooperation in t-1 (0,1 dummy), Technology markets in t-1 (0,1 dummy), Labor markets in t-1(0,1 dummy), Markets for technology in t-1 (0,1 dummy), Consultants' expertise in t-1(0,1 dummy), Firm size in t- 1 (number of employees in logs), Process innovation in t-1 (0,1 dummy), Foreign capital in t-1 (ratio), Industry export intensity (ratio), Low-tech industry (0,1 dummy), Medium-low-tech industry (0,1 dummy), Medium-high-tech industry (0,1 dummy), year dummies. (iii) After completing the matching, differences in the average of the variables used in the probit model were not statistically significant at

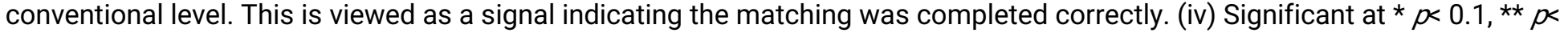
0.05 , *** $p<0.01$. 
Table 4. Regression Results for Knowledge-Sourcing Dimensions

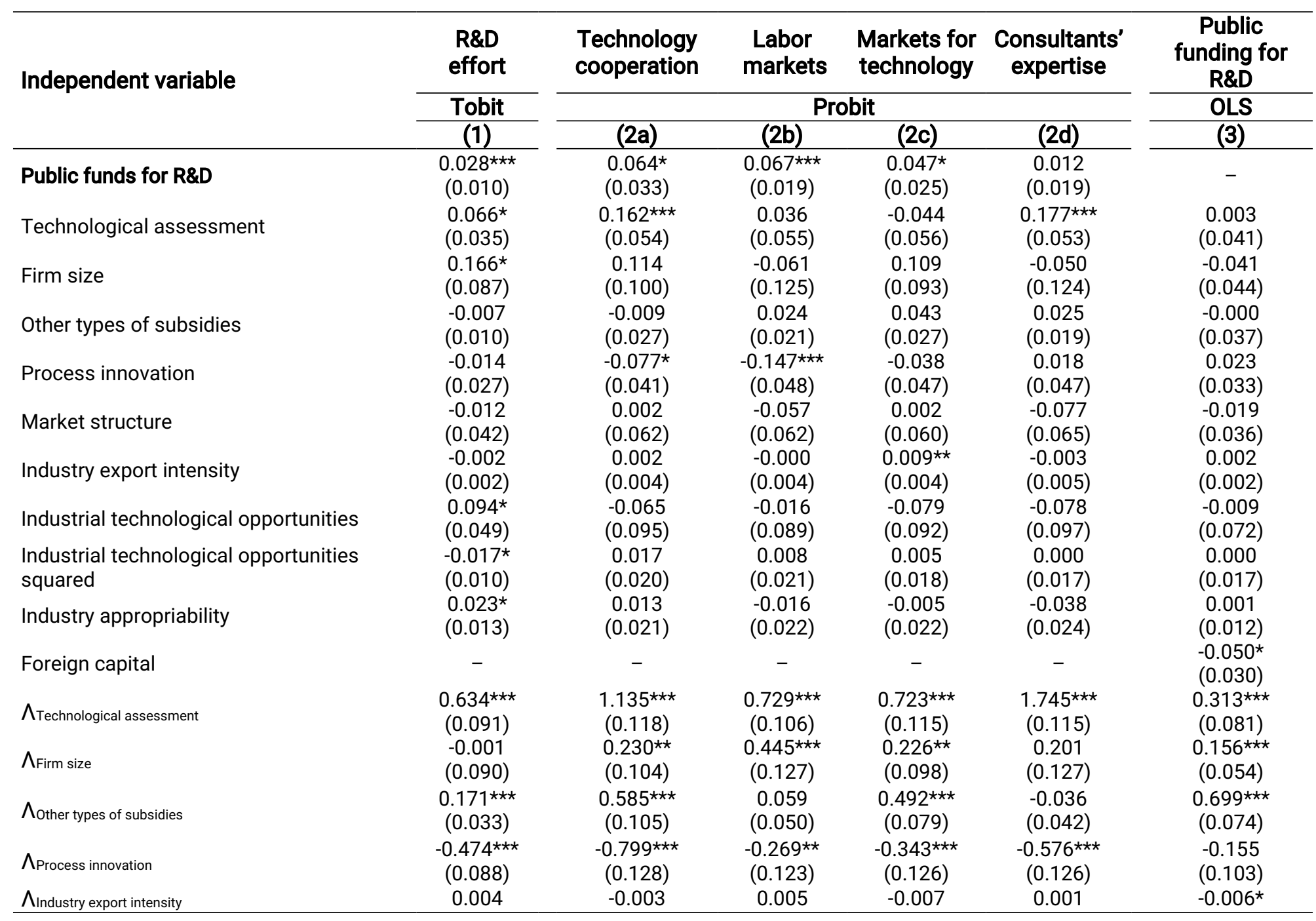




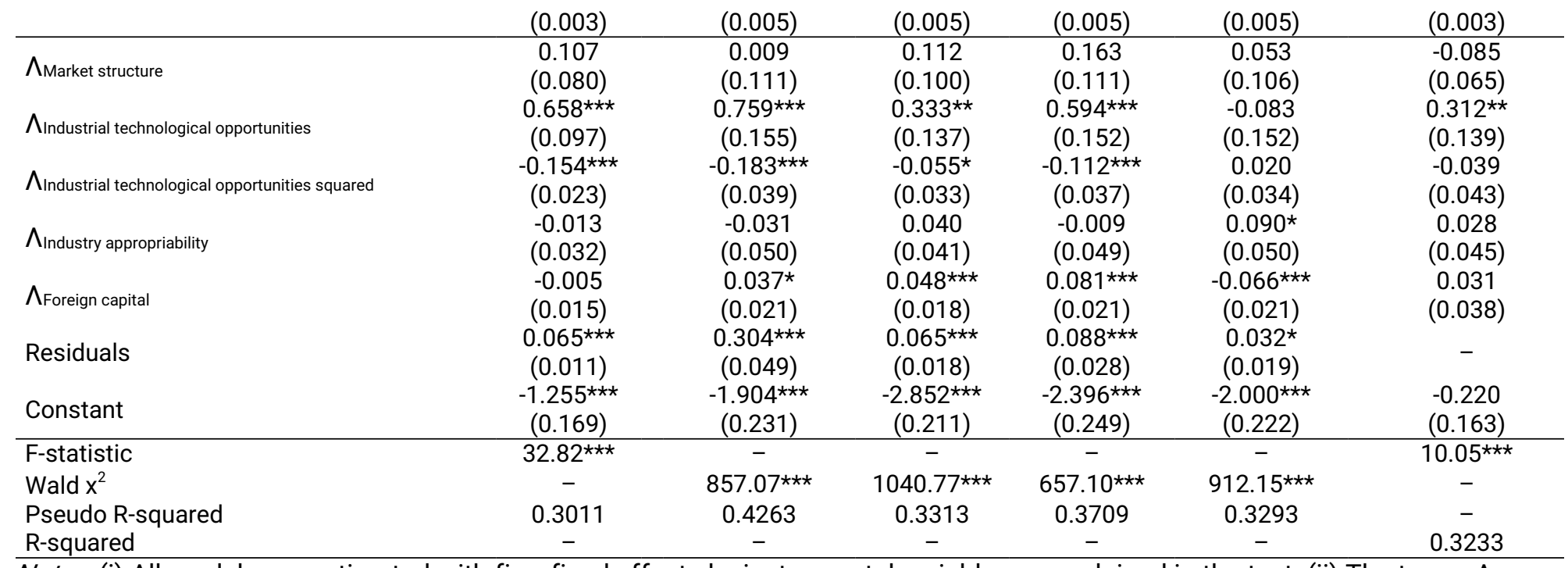

Notes. (i) All models are estimated with firm fixed effects by instrumental variables as explained in the text. (ii) The terms $\Lambda_{\text {(variable }}$ stand for the firm-level mean of the corresponding variable. These terms are included in in the specifications to account for the presence of firm fixed-effects (iii) The term Residuals refers to the errors of the first-stage estimation reported by the model in column 3. (iv) Explanatory and control variables are measured at $t-1$. (v) Time dummies are included in all the models. (vi)

Standard errors, in parentheses, are clustered by firm so they are robust to heteroscedasticity and serial correlation, (vii) Significant at: ${ }^{*} p<0.1, * \star p<0.05, * \star \star p<0.01$. 
Table 5. Regression Results for Firms' Innovative Performance

\begin{tabular}{|c|c|c|c|c|}
\hline \multirow{2}{*}{ Independent variable } & \multicolumn{2}{|c|}{ Number of patents } & \multicolumn{2}{|c|}{$\begin{array}{l}\text { New product } \\
\text { introductions }\end{array}$} \\
\hline & (4a) & (4b) & (5a) & (5b) \\
\hline Lag in the number of patents & $\begin{array}{c}-0.186 * \star \star \\
(0.022)\end{array}$ & $\begin{array}{c}-0.212^{\star \star \star} \\
(0.006)\end{array}$ & - & - \\
\hline Technological assessment & $\begin{array}{l}-0.161 * \star \star \\
(0.033)\end{array}$ & $\begin{array}{l}-0.463^{\star \star \star} \\
(0.012)\end{array}$ & $\begin{array}{l}0.212 * \star \star \\
(0.025)\end{array}$ & $\begin{array}{l}0.213 * \star * \\
(0.013)\end{array}$ \\
\hline Firm size & $\begin{array}{l}0.900 \star \star \star \\
(0.060)\end{array}$ & $\begin{array}{l}0.780 * \star \star \\
(0.030)\end{array}$ & $\begin{array}{l}0.346 * \star * \\
(0.048)\end{array}$ & $\begin{array}{l}0.400 * \star \star \\
(0.032)\end{array}$ \\
\hline Other types of subsidies & $\begin{array}{l}0.026 * \\
(0.015)\end{array}$ & $\begin{array}{c}0.272^{\star \star \star} \\
(0.008)\end{array}$ & $\begin{array}{l}-0.007 \\
(0.008)\end{array}$ & $\begin{array}{c}-0.021^{\star \star *} \\
(0.004)\end{array}$ \\
\hline Process innovation & $\begin{array}{l}0.101 * \star \star \\
(0.023)\end{array}$ & $\begin{array}{l}0.374 \star \star \star \\
(0.011)\end{array}$ & $\begin{array}{c}0.000 \\
(0.030)\end{array}$ & $\begin{array}{l}-0.259 * \star \star \\
(0.015)\end{array}$ \\
\hline Market structure & $\begin{array}{l}1.321^{\star \star \star} \\
(0.106)\end{array}$ & $\begin{array}{c}0.595^{\star \star \star} \\
(0.012)\end{array}$ & $\begin{array}{l}-0.036 \\
(0.048)\end{array}$ & $\begin{array}{l}-0.220 * \star \star \\
(0.016)\end{array}$ \\
\hline Industry export intensity & $\begin{array}{c}-0.011 \star \star \star \star \\
(0.004)\end{array}$ & $\begin{array}{c}-0.017 * \star \star \\
(0.003)\end{array}$ & $\begin{array}{l}-0.004 \\
(0.004)\end{array}$ & $\begin{array}{c}-0.017 * \star \star \\
(0.002)\end{array}$ \\
\hline Industrial technological opportunities & $\begin{array}{l}-0.223^{* \star \star} \\
(0.059)\end{array}$ & $\begin{array}{l}-0.330 \star \star \star \\
(0.019)\end{array}$ & $\begin{array}{c}0.091 \\
(0.130)\end{array}$ & $\begin{array}{l}-0.053 \\
(0.037)\end{array}$ \\
\hline $\begin{array}{l}\text { Industrial technological opportunities } \\
\text { squared }\end{array}$ & $\begin{array}{l}-0.038 \\
(0.041)\end{array}$ & $\begin{array}{l}-0.061 * \star \star \\
(0.012)\end{array}$ & $\begin{array}{l}-0.064 * \star \\
(0.025)\end{array}$ & $\begin{array}{c}-0.053^{\star \star \star} \\
(0.007)\end{array}$ \\
\hline Industry appropriability & $\begin{array}{l}0.282^{\star * *} \\
(0.038)\end{array}$ & $\begin{array}{l}0.123 * \star \star \\
(0.008)\end{array}$ & $\begin{array}{l}0.125^{\star \star \star *} \\
(0.016)\end{array}$ & $\begin{array}{l}0.026 * \star \star \\
(0.007)\end{array}$ \\
\hline Public funds for R\&D & $\begin{array}{c}0.366^{\star \star \star} \\
(0.034)\end{array}$ & $\begin{array}{l}-0.001 \\
(0.008)\end{array}$ & $\begin{array}{l}0.030 \star \star \\
(0.009)\end{array}$ & $\begin{array}{c}0.007 \\
(0.006)\end{array}$ \\
\hline R\&D effort & - & $\begin{array}{c}0.981 * \star \star \\
(0.022)\end{array}$ & - & $\begin{array}{c}0.090 * \star \star \\
(0.008)\end{array}$ \\
\hline Technology cooperation & - & $\begin{array}{c}-0.508 * \star \star \\
(0.028)\end{array}$ & - & $\begin{array}{c}0.228 * * * \\
(0.027)\end{array}$ \\
\hline Labor markets & - & $\begin{array}{c}0.276 * \star \star \\
(0.024)\end{array}$ & - & $\begin{array}{c}0.309 * \star \star \\
(0.014)\end{array}$ \\
\hline Markets for technology & - & $\begin{array}{c}0.637 * \star \star \\
(0.024)\end{array}$ & - & $\begin{array}{l}-0.104 * \star \star \\
(0.029)\end{array}$ \\
\hline Consultants' expertise & - & $\begin{array}{l}1.251 * \star \star \\
(0.050)\end{array}$ & - & $\begin{array}{l}0.072 \star \star \star \\
(0.016)\end{array}$ \\
\hline \multicolumn{5}{|l|}{ Test for serial correlation } \\
\hline First-order correlation & $-2.181^{\star \star}$ & $-2.731^{\star \star}$ & 0.239 & 0.680 \\
\hline Second-order correlation & -1.191 & -1.164 & -1.540 & -1.160 \\
\hline \multicolumn{5}{|l|}{ Over-identification test } \\
\hline Sargan test & 86.637 & 132.4375 & 98.0432 & 214.7790 \\
\hline$P$ value & 0.1315 & 0.3761 & 0.2637 & 0.3056 \\
\hline
\end{tabular}

Notes:(i) Parameters are two-step GMM estimators using Wooldridge moment conditions.

Estimations assume that firm-level explanatory variables should be taken as predetermined. Therefore, past values of these variables are used as valid instruments. (ii) Lag values of the dependent variable are also used as instruments in the models of columns 5 and 6 . A maximum of six lags for each predetermined variable was implemented in each of the specifications. (iii) Time dummies are considered in all models. In the case of dynamic specifications (columns 4a and $4 \mathrm{~b}$ ), time dummies are included as instruments. (iv) The measure of public funds for R\&D, along with all the control variables, is measured at time $t-2$. The variables for $R \& D$ effort and openness in innovation are measured at time $t-1$. Robust standard errors in parentheses. $(v)$

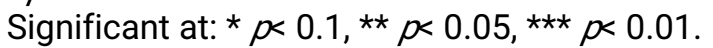


Table 6. Results Bootstrap Test (Open Innovation Strategies and R\&D Effort)

\begin{tabular}{lccccc}
\hline Dependent & \multicolumn{2}{c}{ Effects } & & Bootstrap & \multicolumn{2}{c}{ Confidence interval (95\%) } \\
\cline { 2 - 3 } variable & Origen & Size & standard error & Lower limit & Upper limit \\
\hline \multirow{4}{*}{ Patent } & R\&D effort & 0.049 & 0.009 & 0.034 & 0.067 \\
applications & Cooperation & -0.018 & 0.006 & -0.300 & -0.006 \\
& Labor markets & 0.005 & 0.002 & 0.001 & 0.010 \\
& Tech markets & 0.009 & 0.003 & 0.004 & 0.016 \\
& Consultants & 0.004 & 0.002 & 0.002 & 0.007 \\
& Direct effect & 0.177 & 0.034 & 0.121 & 0.248 \\
\hline \multirow{4}{*}{ New product } & R\&D effort & 0.034 & 0.007 & 0.020 & 0.049 \\
introductions & Cooperation & 0.044 & 0.009 & 0.029 & 0.065 \\
& Labor markets & 0.001 & 0.003 & -0.004 & 0.006 \\
& Tech markets & 0.008 & 0.004 & 0.001 & 0.016 \\
& Consultants & 0.004 & 0.002 & 0.001 & 0.008 \\
& Direct effect & 0.011 & 0.020 & -0.026 & 0.052 \\
\hline
\end{tabular}

Notes. Number of bootstraps samples for bias corrected bootstrap confidence intervals is equal to 1,000 . 